\title{
Differential Gene Expression of Brachypodium distachyon Roots Colonized by Gluconacetobacter diazotrophicus and the Role of BdCESA8 in the Colonization
}

\author{
Xuan Yang, ${ }^{1,2}$ Kathleen A. Hill, ${ }^{1}$ Ryan S. Austin, ${ }^{2}$ and Lining Tian $^{2, \dagger}$ \\ ${ }^{1}$ Department of Biology, University of Western Ontario, London, ON N6A 5B7, Canada \\ ${ }^{2}$ London Research and Development Centre, Agriculture and Agri-Food Canada, London, ON N5V 4T3, Canada
}

Accepted 30 June 2021.

\begin{abstract}
Alternatives to synthetic nitrogen fertilizer are needed to reduce the costs of crop production and offset environmental damage. Nitrogen-fixing bacterium Gluconacetobacter diazotrophicus has been proposed as a possible biofertilizer for monocot crop production. However, the colonization of $G$. diazotrophicus in most monocot crops is limited and deep understanding of the response of host plants to $G$. diazotrophicus colonization is still lacking. In this study, the molecular response of the monocot plant model Brachypodium distachyon was studied during $G$. diazotrophicus root colonization. The gene expression profiles of $B$. distachyon root tissues colonized by $G$. diazotrophicus were generated via next-generation RNA sequencing, and investigated through gene ontology and metabolic pathway analysis. The RNA sequencing results indicated that Brachypodium is actively involved in $G$. diazotrophicus colonization via cell wall synthesis. Jasmonic acid, ethylene, gibberellin biosynthesis. nitrogen assimilation, and primary and secondary metabolite pathways are also modulated to accommodate and control the extent of $G$. diazotrophicus colonization. Cellulose synthesis is significantly downregulated during colonization. The loss of function mutant for Brachypodium cellulose synthase 8 (BdCESA8) showed decreased cellulose content in xylem and increased resistance to $G$. diazotrophicus colonization. This result suggested that the cellulose synthesis of the secondary cell wall is involved in $G$. diazotrophicus colonization. The results of this study provide insights for future research in regard to gene manipulation for efficient colonization of nitrogen-fixing bacteria in Brachypodium and monocot crops.
\end{abstract}

Keywords: BdCESA8, Brachypodium distachyon, cellulose synthesis, colonization, differential gene expression, Gluconacetobacter diazotrophicus

${ }^{\dagger}$ Corresponding author: L. Tian; lining.tian@canada.ca

Funding: This research was supported by Agriculture and Agri-Food Canada and a Natural Science and Engineering Research Council of Canada Discovery Grant.

*The $\boldsymbol{e}$-Xtra logo stands for "electronic extra" and indicates that supplementary materials are published online.

The author(s) declare no conflict of interest. distributed under the CC BY-NC-ND 4.0 International license.
Monocot crops provide over $70 \%$ of global human calories directly or indirectly, with the majority of this coming from members of the grass family Poaceae such as wheat, rice, and maize (Cassman et al. 2003; Brutnell et al. 2015). With the rising human population, the demand for monocot crop production will increase. In the last 50 years, 50 to $60 \%$ of the global crop production increase is attributed to the application of large amounts of synthetic fertilizer, especially synthetic nitrogen $(\mathrm{N})$ fertilizer (Erisman et al. 2008; Kant et al. 2011). Over 50\% of N fertilizer consumption occurs in the production of monocot crops and it accounts for 20 to $30 \%$ of the production cost (Brunelle et al. 2015; Fischer et al. 2009; Ladha et al. 2016). Therefore, any increase in monocot crop production inevitably leads to a higher demand for $\mathrm{N}$ fertilizer. However, researchers have shown that only 25 to $40 \%$ of the applied $\mathrm{N}$ fertilizer is taken up by plants, while over $60 \%$ is lost to the environment through leaching, runoff, denitrification, and gaseous emission (Lassaletta et al. 2014; Sharma and Bali 2018). This N loss becomes the cause of some serious environmental problems such as nutrient depletion in soil, eutrophication in waterbodies, and air pollution (Fowler et al. 2013; Hirel et al. 2011; Zhang et al. 2015). A more sustainable alternative to synthetic $\mathrm{N}$ fertilizer is to use $\mathrm{N}$-fixing bacteria to supply part or all of the nitrogen required by the plant (Besset-Manzoni et al. 2018; Dent and Cocking 2017; Ke et al. 2019).

Based on well-studied legume-rhizobium symbiosis, plants can actively interact with rhizobia at a molecular level. Nodfactor receptors NFR1 and NFR5 are essential for receiving and recognizing the Nod factor signal molecules secreted by rhizobia (Gust et al. 2012; Radutoiu et al. 2003). Following the perception of Nod factors, the symbiosis receptor-like kinases are required for signal transduction to activate other downstream symbiosis-related genes such as early nodulin genes for nodule formation (Gherbi et al. 2008; Stracke et al. 2002). After the rhizobia enter the plant, a mild plant defense response is triggered to control the spread of the microorganism and to prevent the microbial overgrowth in the plant (Iniguez et al. 2005; Nakagawa et al. 2011; Reinhold-Hurek and Hurek 2011). The plant defense response is initiated mainly through salicylic acid (SA)-, jasmonic acid (JA)-, and ethylene (ET)-regulated signaling pathways (Reinhold-Hurek and Hurek 2011). The signaling pathway in legume-rhizobium symbiosis is highly conserved and is required in the most widespread and ancient symbiosis between plants and arbuscular mycorrhizal (AM) fungi (MacLean et al. 2017; Zuccaro and Langen 2020).

As the interface between plants and their environment, the cell wall is essential for plant sensing and adapting to external stimuli, including response to microbes (Bacete et al. 2018; 
Malinovsky et al. 2014; Miedes et al. 2014). Cell walls consist of various components and the main components include cellulose, hemicellulose, pectin, and lignin (Loqué et al. 2015; Pauly and Keegstra 2008). Many microbes enter into plants by secreting cell-wall-degrading enzymes to hydrolyze different cell wall components (Hématy et al. 2009; Malinovsky et al. 2014). Once the cell wall is compromised, cell wall fragments such as cellulose-derived cellobiose act as signaling molecules to trigger the plant immune response (Brutus et al. 2010; Souza et al. 2017). Cellulose is a predominant cell wall component and is synthesized by the cellulose synthase catalytic subunits (CESAs) in the cellulose synthase complex (Endler and Persson 2011). In Arabidopsis, members of a family of 10 genes are identified as CESA genes (Endler and Persson 2011). The current understanding of the CELLULOSE SYNTHASE A (CESA) gene family suggest that CESA1, CESA3, and CESA6 are essential for primary cell wall synthesis and CESA4, CESA7, and CESA 8 are necessary for secondary cell wall formation (Persson et al. 2007; Taylor et al. 2003). CESA2, CESA5, and CESA9 have a partially redundant function like CESA6 (Desprez et al. 2007). CESA2, CESA5, and CESA9 are also involved in the formation and thickening of the secondary radial wall of seed coat epidermal cells (Mendu et al. 2011; Stork et al. 2010; Sullivan et al. 2011). Studies has demonstrated that impairment of CESAs can lead to changes in resistance of microbial infections via activation of different defense hormones and ectopic lignin production (Denness et al. 2011; Hamann 2012; Hernández-Blanco et al. 2007).

Gluconacetobacter diazotrophicus is an endophytic N-fixing bacterium originally isolated from sugarcane (Cavalcante and Dobereiner 1988). Studies have demonstrated that G. diazotrophicus can significantly reduce the amount of $\mathrm{N}$ fertilizer used in sugarcane production (Boddey et al. 2001; Sevilla et al. 2001). Unlike Rhizobia bacteria, G. diazotrophicus does not form specific organ-like nodules in its host plant and has a broad host range (Jimenez-Salgado et al. 1997; Paula et al. 1991; Tapia-Hernández et al. 2000). Since the discovery of G. diazotrophicus, researchers have successfully introduced $G$. diazotrophicus into several monocot crops, including rice (Sevilla and Kennedy 2000; Silva et al. 2020), corn (Tian et al. 2009), wheat (Luna et al. 2010), sorghum (Yoon et al. 2016), and miscanthus (Fei et al. 2020), as well as the dicot model plant Arabidopsis (Rodriguez et al. 2019). However, the molecular mechanisms involved in $G$. diazotrophicus colonization in these crop plants are still largely unclear (Farrar et al. 2014; Zamioudis and Pieterse 2012) due to the genome complexity and long life cycle of most monocot crops and the lack of monocot species with an extensive mutant collection. This has affected further investigation and use of $G$. diazotrophucus for $\mathrm{N}$ fixation in various monocot crops.

Brachypodium distachyon (referred to hereafter as Brachypodium) has recently emerged as a new model species for molecular biology research in monocot plants (Brkljacic et al. 2011; Brutnell et al. 2015; Scholthof et al. 2018) due to its simple growth requirements, short life cycle, and small genome (Febrer et al. 2010; Vain 2011). The full genome sequence of Brachypodium (Bd21) was published in 2010 (The International Brachypodium Initiative 2010) and a large T-DNA collection containing 23,649 mutant lines has been developed for researchers to use (Bragg et al. 2012; Hsia et al. 2017; Thole et al. 2012). These advancements made in research tools and materials have facilitated the intensive development of Brachypodium research in the past decade The findings of this research offered insights on manipulation of monocot plant-microbe interaction by altering cell wall compositions through cellulose synthase (CESA) and phenylalanine ammonia lyase $(P A L)$ gene families (Cass et al. 2015; Petrik et al. 2016). Thus, these resources make Brachypodium an excellent choice for studying the interaction between monocot plants and G. diazotrophicus.

Understanding the molecular mechanisms of N-fixing bacterium colonization in plants is essential for developing effective interactions between the bacteria and their hosts, and for efficient $\mathrm{N}$ fixation in the plant host. The aim of this study is to investigate the transcriptional response of Brachypodium to $G$. diazotrophicus colonization and to identify genes that are potentially involved in the interaction between Brachypodium and $G$. diazotrophicus.

\section{RESULTS}

\section{RNA sequencing quality and the distribution of differentially expressed genes.}

Illumina sequencing produced over 30 million paired-end reads for each of the three biological replicates. The reads were mapped to the Brachypodium reference and more than 20 million reads from each replicate were able to be mapped. These reads aligned to over $86 \%$ of genes in the Brachypodium genome (Supplementary Table S1). The gene expression profiles within the control samples and within the colonized samples were highly correlated; the correlation values were 0.97 and 0.98 for the control group and the colonized group, respectively (Pearson correlation). The gene expression profiles of control samples and colonized samples were clearly distinct from each other (Supplementary Fig. S1). In total, 1,595 genes were identified as differentially expressed (fold change $>1.5, P \leq 0.01$ ) between the control and colonized samples. The most frequently used cut-off for differential gene expression in RNA sequencing are 2-fold change and 1.5-fold change (Bhargava et al. 2013; Cardoso et al. 2017; Zhao et al. 2018). The lower cut-off of fold change of $>1.5$ was employed to cover a wider range of genes that responded to G. diazotrophicus colonization because colonization is a dynamic process and the induced expression of some early responsive genes may change at the later stage of colonization. There were 659 genes that were downregulated and 936 genes that were upregulated (Supplementary Fig. S2; fold change was $\log _{2}$ transformed and $P$ value is false discovery rate [FDR] corrected). To verify the RNA sequencing results, quantitative PCR (qPCR) analysis was conducted for 15 randomly selected genes from the differentially expressed genes and the qPCR results were consistent with the RNA-sequencing results. The general trends of the expression change were found to be the same in both RNA sequencing and qPCR analysis (Supplementary Table S2).

\section{G. diazotrophicus colonization induced an array of transcriptional responses in Brachypodium.}

Although only 380 of the 1,595 differentially expressed genes matched annotation on the metabolic map, further analysis displayed a clear picture about specific pathways. There are more pathways downregulated than pathways upregulated (Table 1), although the number of upregulated genes is higher than the number of downregulated genes. The strongly downregulated metabolic pathways included JA biosynthesis, ET biosynthesis, nitrate reduction, and fatty acid and lipid biosynthesis. The strongly upregulated pathways included gibberellin (GA) biosynthesis, flavonoid biosynthesis, and phenylpropanoid biosynthesis. The MapMan pathway analysis mapped 453 differentially expressed genes in biotic stress responsive pathways. The major pathways included cell-wall-related processes, hormone signaling pathways, signaling transduction pathways, and heat shock protein and secondary metabolite pathways (Fig. 1). These results indicate that Brachypodium may respond to $G$. diazotrophicus colonization by slowing down host $\mathrm{N}$ assimilation, increasing plant growth via hormone modulation, and altering 
primary and secondary metabolite biosynthesis such as flavonoid and phenylpropanoid synthesis to accommodate the bacteria.

Gene ontology (GO) annotation data are summarized into three categories: biological process, molecular function, and cellular component. For the 1,595 differentially expressed genes, 1,218 genes were annotated in the biological process category, 728 genes were annotated in the molecular function category, and 856 genes were annotated in the cellular component category. Under the biological process category, metabolic process $(33.4 \%)$ is the largest

Table 1. Major metabolic pathways identified with the differential expression data

\begin{tabular}{lcc}
\hline Pathway & Genes $^{\mathbf{z}}$ & $\begin{array}{c}\text { Primary change in } \\
\text { gene expression }\end{array}$ \\
\hline Jasmonic acid biosynthesis & 7 & Down \\
Ethylene biosynthesis & 4 & Down \\
Nitrate reduction & 3 & Down \\
Ammonia assimilation & 2 & Down \\
Fatty acid biosynthesis & 17 & Down \\
Gluconeogenesis & 3 & Down \\
Brassinosteroid biosynthesis & 5 & Down \\
Gibberellin biosynthesis & 3 & Up \\
Flavonoid biosynthesis & 5 & Up \\
Phenylpropanoid biosynthesis & 6 & Up \\
Xyloglucan biosynthesis & 2 &
\end{tabular}

${ }^{2}$ Number of mapped genes $=$ the number of differentially expressed genes that can be overlaid onto the Brachypodium metabolic pathways map. group, followed by cellular process $(30.5 \%)$ (Supplementary Fig. S3a). Under the molecular function category, the largest group is catalytic activity $(53.1 \%)$, followed by binding (21.9\%) (Supplementary Fig. S3b). Under the cellular component category, the largest group is cell part $(50.6 \%)$, followed by organelle $(27.5 \%)$ (Supplementary Fig. S3c).

GO term enrichment was tested for all differentially expressed genes under the biological process category. The top six most significantly enriched biological processes $(P \leq 0.05)$ were plant-type cell wall biogenesis, cellulose metabolic process, plant-type cell wall organization, hydrogen peroxide catabolic process, cellular oxidant detoxification, and oxidation-reduction process (Table 2). The first three of these six processes are cellwall-related processes, which suggests that cell-wall-related processes, especially cell wall synthesis, were significantly downregulated in Brachypodium after the colonization of G. diazotrophicus.

\section{Downregulation of Brachypodium cellulose synthase family during $\boldsymbol{G}$. diazotrophicus colonization.}

Cellulose is a dominant component of the cell wall, constituting 40 to $50 \%$ of its make-up. Hemicellulose and lignin represent 28 to 37 and 13 to $28 \%$ of the cell wall, respectively (Loqué et al. 2015; Pauly and Keegstra 2008). Among the major cell wall components, the cellulose metabolic process was highlighted as the second most enriched process in the enrichment analysis. There were 14 differentially expressed genes in

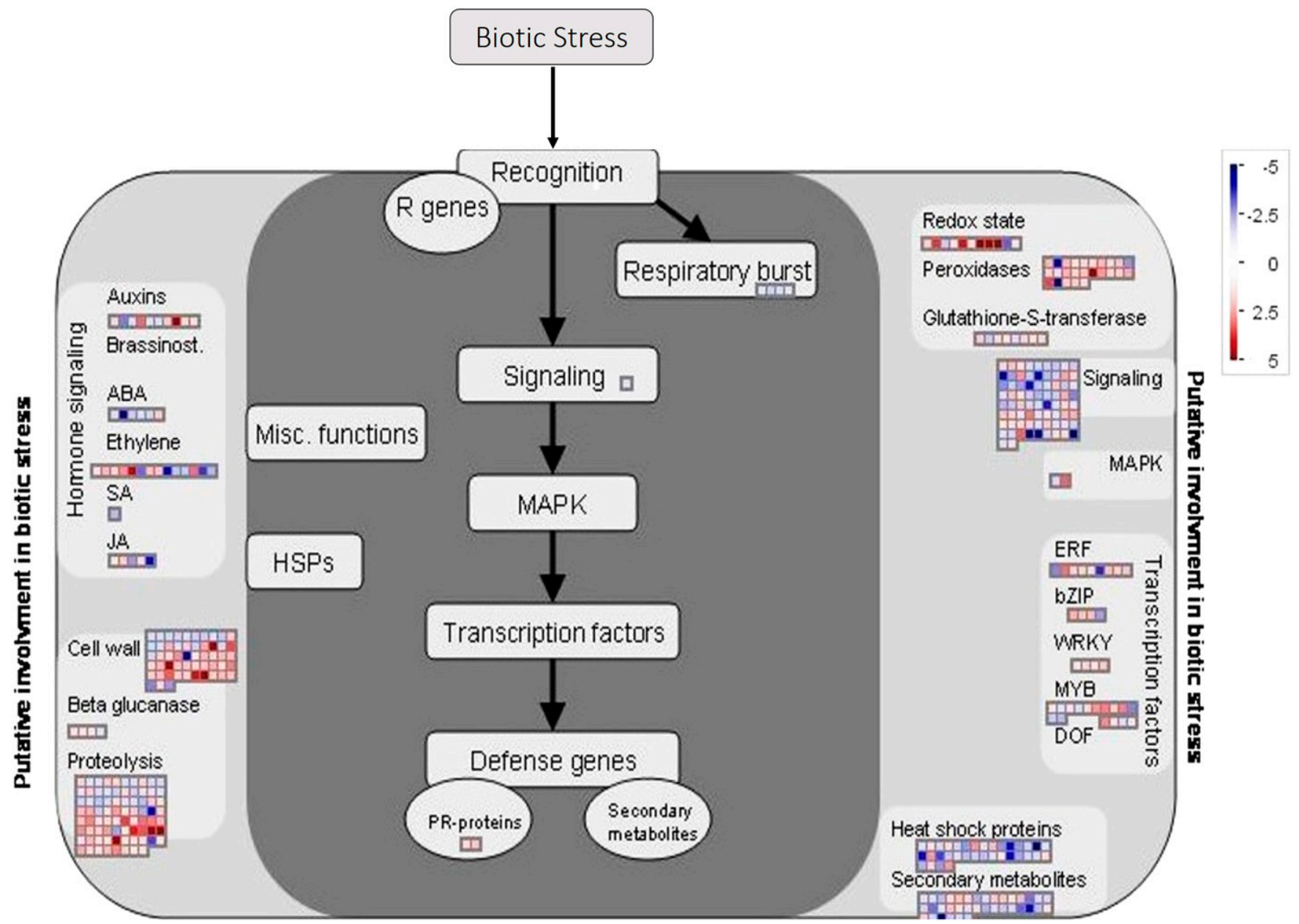

Fig. 1. Differentially expressed genes that are involved in biotic stress responsive pathways. Red squares represent upregulated pathways and blue squares represent downregulated pathways. 
this process and half of them were annotated as CESA or uncharacterized cellulose synthase-like genes. This implies that cellulose synthesis was strongly modulated after colonization by G. diazotrophicus, and Brachypodium CESA genes should be a focus for subsequent studies.

Based on previous studies, a BLAST search using Arabidopsis thaliana CESA family genes sequences, and a key word search using cellulose synthase in the annotated Brachypodium genome at Phytozome, Brachypodium has 10 genes annotated as CESA family genes. Five of these CESA genes were on the gene list of cellulose metabolic process in our enrichment analysis (Table 3). Most knowledge about the plant CESA gene family was gained from experiments in A. thaliana and rice (Oryza sativa) (Tanaka et al. 2003; Taylor et al. 2000). Therefore, to gain an understanding of the functions of Brachypodium CESA genes, a phylogenetic comparison was conducted for all CESA family members in A. thaliana, rice, and Brachypodium using their amino acid sequences. Based on the current understanding of the plant CESA family, CESA 1, 3, 6, and 9 clades function mainly in primary cell wall synthesis, while CESA 4 , 7, and 8 clades work in secondary cell wall synthesis. According to the phylogenetic analysis, two (BdCESA3: Bradilg54250 and BdCESA6: Bradilg53207) of the five CESA genes in the enrichment analysis are involved in primary cell wall synthesis, and the other three CESA genes (BdCESA4: Bradi3g28350, BdCESA7: Bradi4g30540, and BdCESA8: Bradi2g49912) are essential genes involved in secondary cell wall synthesis (Fig. 2). This finding indicates that cellulose synthesis in the secondary cell wall was significantly downregulated in Brachypodium during the colonization process of $G$. diazotrophicus. Hence, hypothetically,

Table 2. Enrichment analysis of the differentially expressed genes annotated to the gene ontology (GO) category of biological processes

\begin{tabular}{|c|c|c|c|}
\hline Biological process & $\begin{array}{c}\text { Fold } \\
\text { enrichment }\end{array}$ & $P$ value $^{\mathrm{z}}$ & $\begin{array}{l}\text { Number } \\
\text { of genes }\end{array}$ \\
\hline $\begin{array}{l}\text { Plant-type cell wall biogenesis } \\
\text { (GO:0009832) }\end{array}$ & 8.33 & 4.64E-02 & 7 \\
\hline $\begin{array}{l}\text { Cellulose metabolic process } \\
\text { (GO:0030243) }\end{array}$ & 4.67 & $5.46 \mathrm{E}-03$ & 14 \\
\hline $\begin{array}{l}\text { Plant-type cell wall organization } \\
\text { (GO:0009664) }\end{array}$ & 4.43 & $3.41 \mathrm{E}-09$ & 34 \\
\hline $\begin{array}{l}\text { Hydrogen peroxide catabolic } \\
\text { process } \\
\text { (GO:0042744) }\end{array}$ & 2.98 & $1.64 \mathrm{E}-03$ & 27 \\
\hline $\begin{array}{l}\text { Cellular oxidant detoxification } \\
\text { (GO:0098869) }\end{array}$ & 2.50 & $3.56 \mathrm{E}-03$ & 34 \\
\hline $\begin{array}{l}\text { Oxidation-reduction process } \\
\text { (GO:0055114) }\end{array}$ & 1.49 & $5.86 \mathrm{E}-03$ & 137 \\
\hline
\end{tabular}

Table 3. Members of the cellulose synthase family in Brachypodium ${ }^{\mathrm{z}}$

\begin{tabular}{lc}
\hline Gene & $\begin{array}{c}\text { Fold change in RNA } \\
\text { sequencing }\end{array}$ \\
\hline$B d C E S A 1:$ Bradi2g34240 & -1.45 \\
$B d C E S A 2:$ Bradi1g04597 & $\mathrm{NA}$ \\
BdCESA3: Bradi1g54250 & $\mathbf{- 1 . 5 6}$ \\
BdCESA4: Bradi3g28350 & $\mathbf{- 1 . 8 2}$ \\
BCESA5: Bradi1g29060 & -1.43 \\
BdCESA6: Bradi1g53207 & $\mathbf{- 1 . 8 7}$ \\
BdCESA7: Bradi4g30540 & $\mathbf{- 1 . 6 4}$ \\
BdCESA8: Bradi2g49912 & $\mathbf{- 1 . 7 2}$ \\
BCESA9: Bradi1g02510 & -1.47 \\
BdCESA10: Bradi1g36740 & $\mathrm{NA}$ \\
\hline
\end{tabular}

${ }^{\mathrm{z}} \mathrm{NA}$ indicates expression not detected in RNA sequencing. Genes in bold were significantly regulated based on the enrichment analysis. disruption of the cellulose synthesis in the secondary cell wall can influence the colonization of $G$. diazotrophicus in Brachypodium. BdCESA4, BdCESA7, and BdCESA8 are potential candidate genes for further studies. The downregulation of $B d C E S A 4, B d C E S A 7$, and $B d C E S A 8$ expression in RNA sequencing results was validated by qPCR analysis (Supplementary Table S2). BdCESA8 was chosen for later study in this research due to the availability of the BdCESA8 T-DNA mutant.

\section{Mutation of $B d C E S A 8$ gene produces changes of aboveground phenotypes.}

The insertion site of a T-DNA disrupting the BdCESA8 gene is located at the nineth exon. The insertion site and genotyping primers design are shown in Supplementary Fig. S4a and a sample of the genotyping PCR result is displayed in Supplementary Fig. S4b. The aboveground phenotypes of BdCESA8 T-DNA mutant line JJ1828 were evaluated during propagation. The heterozygous $B d C E S A 8$ T-DNA mutant plants did not exhibit any apparent phenotypic difference from wild-type $\mathrm{Bd} 21-3$ plants. However, the homozygous BdCESA 8 mutant plants showed a severe dwarf phenotype, because the stems were much shorter and softer (Fig. 3A). The homozygous mutant plants were also completely sterile, although the spikelets were normally formed (Fig. 3B). All of the mutant plants used in later experiments were propagated from seed harvested from heterozygous plants. The segregation rate for the homozygous individuals is $23.5 \%$ (from $n=285,67$ plants were homozygous), which is very close to the theoretical segregation ratio $1 / 4$ according to Mendel's Law of Segregation $\left(\chi^{2}\right.$ test, $\left.P=0.3158\right)$.

We performed qPCR and the the expression of BdCESA 8 in heterozygous mutant plants decreased to $43 \%$ compared with the expression level in wild-type plants. The expression of BdCESA8 in homozygous mutant plants decreased dramatically to almost zero when compared with wild-type plants (Fig. 3C). The phenotypes of the homozygous BdCESA8 mutant indicated that $B d C E S A 8$ may function mainly in stem and seed development.

\section{G. diazotrophicus colonization is inhibited in a BdCESA8 T-DNA homozygous mutant.}

Before performing the colonization experiments, the root phenotypes were examined because the root is the site for G. diazotrophicus colonization. The length of primary roots and the number of lateral roots from each genotype group were measured. The results showed that there was no significant difference between wild-type, heterozygous, and homozygous BdCESA 8 mutants in both primary root length (Supplementary Fig. S5a) and the number of lateral roots (Supplementary Fig. $\mathrm{S} 5 \mathrm{~b})$. This indicates that there is no obvious morphological difference belowground between wild-type and BdCESA 8 mutant plants.

To determine the effect of mutation in BdCESA8 on G. diazotrophicus colonization, the colonization experiments were conducted with BdCESA8 T-DNA mutants and wild-type plants. For the wild-type group, $23.9 \%$ of plants $(n=214)$ were successfully colonized by $G$. diazotrophicus. For the heterozygous BdCESA 8 mutant group, $16.96 \%$ of plants $(n=112)$ showed $G$. diazotrophicus colonization. There was no $G$. diazotrophicus colonization observed in the homozygous BdCESA8 mutant group $(n=46)$. Results show that wild-type and heterozygous mutants had no significant difference for $G$. diazotrophicus colonization, while there was no $G$. diazotrophicus colonization for the homozygous mutants (Table 4). The pattern of G. diazotrophicus colonization in heterozygous mutants was also similar to the pattern seen in the wild-type plants. The bacteria entered the plants through lateral root emergence sites and then spread into primary roots (Fig. 4). 
Cellulose synthesis decreases significantly in the root xylem of the BdCESA 8 homozygous mutant.

The functions of $B d C E S A 8$ in the roots were investigated because the homozygous $B d C E S A 8$ T-DNA mutant responded to $G$. diazotrophicus differently than wild-type and heterozygous mutant plants. BdCESA 8 is annotated as a cellulose synthase involved in secondary cell wall biosynthesis; hence, the cellulose content of secondary cell wall in the roots of BdCESA8 T-DNA mutants was examined.

The microscopic analysis showed that the cellulose content of xylem vessels in homozygous mutants was significantly decreased, but the cellulose content of xylem vessels in heterozygous mutants was essentially unchanged (Fig. 5A and B). The same pattern was observed for the thickness of xylem vessels. The thickness of the xylem vessels in homozygous mutants was greatly reduced but not for xylem vessels in heterozygous mutants (Fig. 5C). These findings suggest that BdCESA 8 is, indeed, involved in the cellulose synthesis of the secondary cell wall in roots. Nonetheless, the deficient cellulose synthesis caused by the BdCESA8 mutation does not lead to the deformation of basic structure of the roots; rather, it only leads to a reduction in the thickness of the xylem vessel to a certain extent.

\section{DISCUSSION}

\section{G. diazotrophicus modulates plant defense response through different phytohormone pathways and $\mathrm{N}$ assimilation to establish colonization.}

Although the colonization of $G$. diazotrophicus did not cause any disease symptoms, it still induced a plant defense response in Brachypodium. This phenomenon is well documented in different studies about beneficial endophyte-plant host interactions. The initial encounter with beneficial endophytes triggers plant defense responses but the beneficial endophyte induces fewer

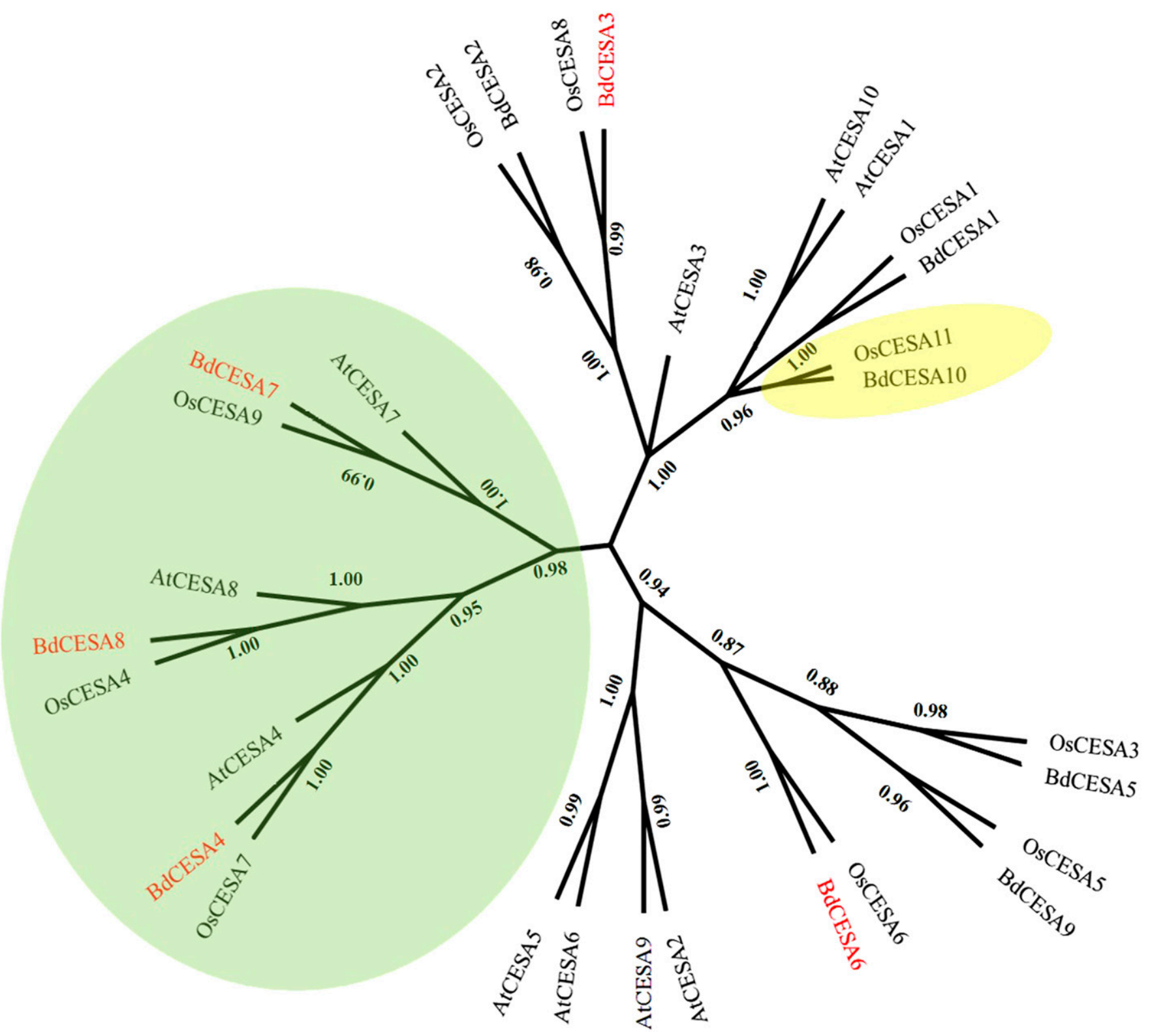

Fig. 2. Phylogenetic analysis of cellulose synthase catalytic subunit (CESA) amino acid sequences in Arabidopsis, rice, and Brachypodium. Numerical values on branches refer to the likelihood of the grouping based on the similarity of the aligned amino acid sequences. The green circle denotes proteins associated with secondary cell walls. The yellow circle shows the proteins with no annotated functions. Proteins that were significantly regulated based on the enrichment analysis are shown in red. The phylogenetic tree is generated by PhyML 3.0 software. 
defense genes compared with a pathogen attack (Bordiec et al. 2011; Miché et al. 2006). Additionally, the defense response is modulated by both endophyte and plant host to a delicate balance via cross talk of different phytohormones (Iniguez et al. 2005; Kudoyarova et al. 2019; Zamioudis and Pieterse 2012). Genes in JA and ET biosynthesis pathways were downregulated whereas genes in the GA biosynthesis pathway were upregulated in Brachypodium during G. diazotrophicus colonization (Table 2). Only a limited number of differentially expressed genes mapped to phytohormone metabolic and signaling transduction pathways in this study. Thus, to understand the extent of the involvement of phytohormones during the colonization, the differential expression profile was compared with some other research on transcriptional responses of Brachypodium to different phytohormones (Cao et al. 2016; Kakei et al. 2015; Powell et al. 2017; Subramanyam et al. 2019). G. diazotrophicus colonization induced transcriptional change in 60 putative abscisic acid (ABA)-responsive genes, 50 putative JA-responsive genes, 10 putative SA-responsive genes, 9 putative auxin-responsive genes, 27 putative GA-responsive genes, and 6 putative ET-responsive genes. (Chen et al. 2005). This observation is in line with the findings of some recent studies on plant defense response to biotic stress (Hernández-Blanco et al. 2007; Lee et al. 2018; Seo and Park 2010). JA and ET pathways are known to be involved in plant resistance of necrotrophic pathogens (Bari and Jones 2009; Conn et al. 2008) and the control of the extent of beneficial endophyte colonization (Liu et al. 2017; Rosenblueth and Martínez-Romero 2006). Endophytes often manipulate other plant hormones to intercept with defense response signaling pathways (Verhage et al. 2010; Zamioudis and Pieterse 2012).
In addition to plant hormone modulation, nitrate reduction was also regulated. Nitric oxide (NO) is generated during nitrate reduction (Crawford and Forde 2002) and it interact with excessive oxygen species to develop a hypersensitive response as a defense mechanism (Delledonne et al. 2001; Yun et al. 2011). NO also initiates microbe-associated molecular pattern (MAMP)-triggered immunity and effector-triggered immunity through SA or JA/ET pathways (Mur et al. 2013; Zeidler et al. 2004). Therefore, downregulating nitrate reduction will reduce the production of $\mathrm{NO}$ and avoid the initiation of the plant defense response, which can aid $G$. diazotrophicus in developing and maintaining colonization in Brachypodium.

Overall, the results in this study indicate that, to create an appropriate host environment to accommodate this beneficial plant-microbe interaction, Brachypodium responds to G. diazotrophicus colonization by slowing down $\mathrm{N}$ assimilation and modulating plant hormone pathways.

Table 4. Percent success of Gluconacetobacter diazotrophicus colonization in BdCESA8 T-DNA mutants ${ }^{\mathrm{y}}$

\begin{tabular}{lccr}
\hline Genotype & $\begin{array}{c}\text { Total } \\
\text { number } \\
\text { of plants }\end{array}$ & $\begin{array}{c}\text { Number of } \\
\text { colonized } \\
\text { plants }\end{array}$ & $\begin{array}{c}\text { Percentage } \\
(\boldsymbol{\%})^{\mathbf{z}}\end{array}$ \\
\hline Wild type & 214 & 49 & $22.90 \mathrm{a}$ \\
Homozygous mutant & 46 & 0 & $0 \mathrm{~b}$ \\
Heterozygous mutant & 112 & 19 & $16.96 \mathrm{a}$ \\
\hline
\end{tabular}

${ }^{\mathrm{y}}$ The proportion of the colonized plants in different genotype groups was compared using a two-tailed $\mathrm{Z}$ test with significance level of 0.05 .

${ }^{\mathrm{z}}$ Different letters indicate the significant difference in success of colonization $(P<0.005)$.
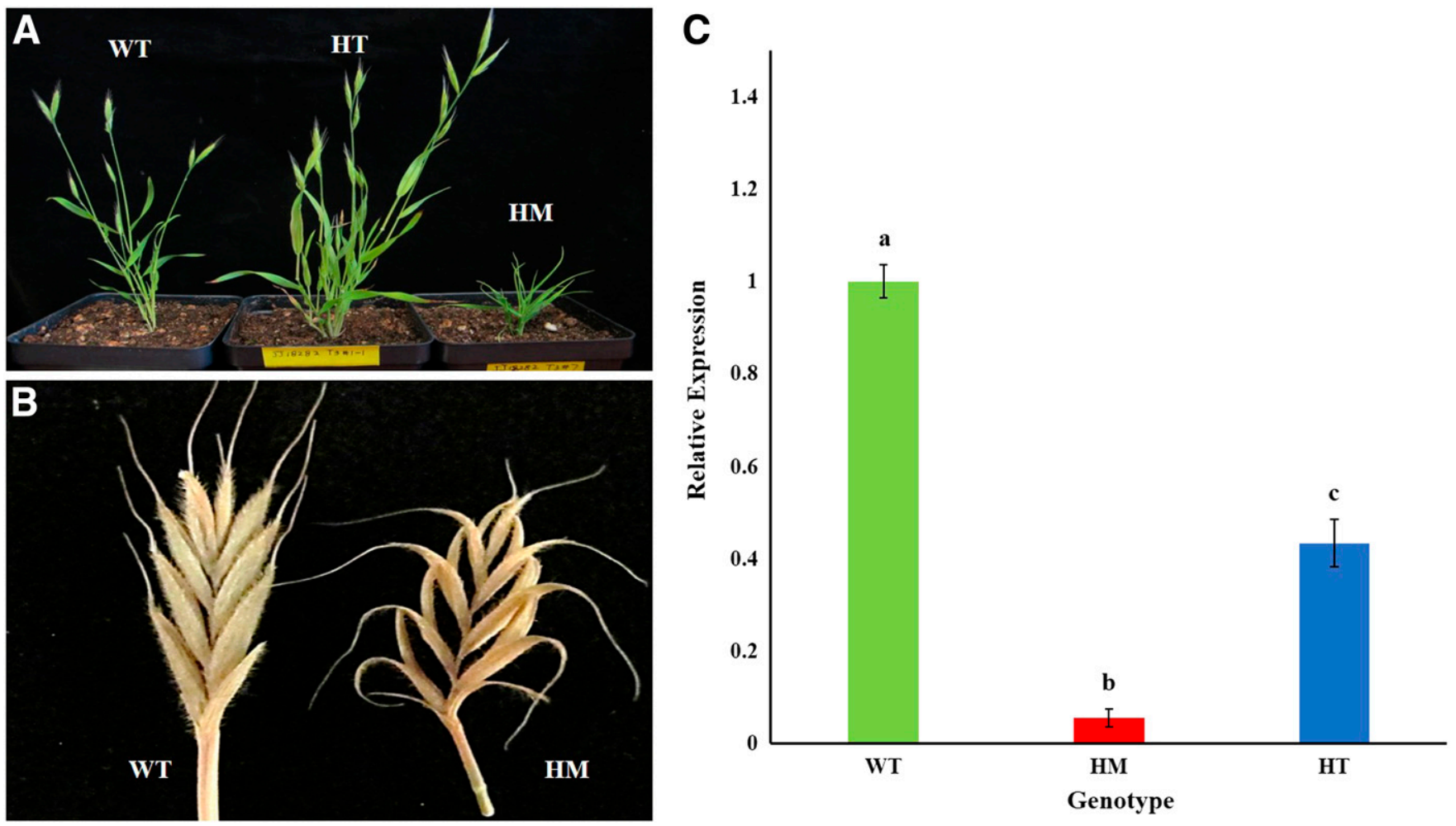

Fig. 3. Phenotypic characteristics and relative expression of BdCESA8 T-DNA insertion mutants. A, Aboveground tissue comparison of BdCESA8 T-DNA mutants and a wild-type (WT) plant. The homozygous mutant (HM) is phenotypically dwarfed, shorter than the WT and the heterozygous mutant (HT). B, Mature spikelets of the WT plant and the BdCESA8 HM. No seed was produced in the spikelet of the HM. C, Expression level of BdCESA8 in T-DNA insertion mutants compared with the WT. Error bars indicate the standard errors of the mean for three biological replicates. Different letters ( $\mathrm{a}, \mathrm{b}$, and $\mathrm{c}$ ) indicate significant differences in the expression levels of BdCESA8 among different genotypes of plants (analysis of variance, $P<0.05)$. 
The role of the secondary cell wall and cellulose synthases in $G$. diazotrophicus colonization.

Based on the pathway and GO enrichment analysis, the cellwall-related processes were significantly regulated during $G$. diazotrophicus colonization (Fig. 1; Table 2). The cell wall is a highly dynamic and regulated structure essential for plant growth and development (Hamann 2012; Pogorelko et al. 2013). In addition to its functions in plant development, the cell wall also plays important roles in plant immunity against microbial invasion. When attempting to colonize plants, the cell wall is the first barrier that microbes confront. To penetrate this barrier, microbes have evolved to secrete cell-wall-degrading enzymes to break down different cell wall components (Hématy et al. 2009; Malinovsky et al. 2014). The impaired cell wall then releases signaling molecules, known as damage-associated molecular patterns (DAMPs), to initiate responses to regulate cell wall integrity (Engelsdorf and Hamann 2014; Voxeur and Höfte 2016). DAMPs consist of cell wall molecular fragments such as oligogalacturonides and cellobiose that are generated during cell wall degradation (Brutus et al. 2010; Kohorn et al. 2009; Souza et al. 2017; Vorwerk et al. 2004). DAMPs can be recognized by pattern recognition receptors and activate plant innate immune responses through molecular mechanisms that are similar to the activation of immune responses by MAMPs (Macho and Zipfel 2014; Malinovsky et al. 2014). Cellulose is a major component of cell walls, and any change in cellulose metabolism could have a significant impact on cell wall integrity and functions. The GO enrichment analysis found that a cellulose metabolic process was strongly downregulated in $G$. diazotrophicus-colonized Brachypodium roots (Table 2). Further phylogenetic analysis revealed that the cellulose synthesis (BdCESA4, -7, and -8) in the secondary cell wall was also influenced by $G$. diazotrophicus colonization (Fig. 4). The secondary cell wall is formed in some cells such as xylem vessels that have completed their cellular expansion and need to be reinforced for functional reasons (Kumar et al. 2016; Sarkar et al. 2009). The roles of the secondary cell wall in plant defense systems has been investigated in plant mutants impaired in different secondary wall components for different endophytes (Malinovsky et al. 2014; Underwood 2012). For example, the Arabidopsis mutants, with defects in cellulose synthase subunits for secondary cell wall formation (CESA4, CESA7, and CESA8), were more resistant to different pathogens such as the fungi Plectosphaerella cucumerina and Botrytis cinerea and the bacteria Ralstonia solanacearum and Pseudomonas syringae (Hernández-Blanco et al. 2007). These results are further supported by experiments on an Arabidopsis mutant with impairment in the MYB46 transcription factor. MYB46 directly regulates the genes that control lignin and cellulose biosynthesis in the secondary cell wall. The MYB46 mutants showed enhanced resistance to $B$. cinerea (Ramírez et al. 2011). In grasses, the effect of modifying lignin biosynthesis on plant immunity has also been investigated. Silencing the monolignol biosynthesis genes PAL, COMT, CCOAOMT, and CAD led to decreased resistance to powdery mildew disease in wheat (Bhuiyan et al. 2009).

Evidence of the contribution of the secondary cell wall to plant immunity for different microbes is still mounting (Miedes et al. 2014; Nafisi et al. 2015). Taking these data together, it is reasonable to extend previous discoveries to our current study and assume that alterations in the secondary cell wall of Brachypodium can affect the colonization of $G$. diazotrophicus. Therefore, the combined GO enrichment analysis and the literature evidence indicates that disruption of BdCESA 8 causes defects in secondary cell wall cellulose synthesis and, consequently, alters the outcome of $G$. diazotrophicus colonization. This is supported by the results of the $G$. diazotrophicus colonization experiment on the BdCESA8 mutant (Table 4). Heterozygous BdCESA8 mutants have cellulose content in xylem and colonization patterns similar to those in wild-type plants, whereas homozygous BdCESA8 mutants contain significantly less cellulose content in xylem and are resistant to G. diazotrophicus colonization (Fig. 5; Table 4). Together, these results suggested that the function of BdCESA8 is not inhibited by the T-DNA insertion in the heterozygous mutant, and the normal cellulose synthesis in xylem is not dependent on the transcription level of BdCESA8. The T-DNA mutation in BdCESA8 is a recessive mutation and requires a homozygous mutant to reveal the mutant phenotype and the function of BdCESA8. Therefore, the failure of G. diazotrophicus colonization in the homozygous mutant is a reflection of the involvement of BdCESA8 in colonization. In this study, the synthesis of the secondary cell wall was not checked after plants were grown in Prox-Mix because there could be a possible impact of AM fungi that can colonize most land plants.

\section{Enhanced resistance to $G$. diazotrophicus colonization in the $B d C E S A 8$ mutant is likely mediated through ABA pathways.}

It has been reported that disruption of the CESA8 gene increased ABA accumulation in plants (Chen et al. 2005). Researchers also demonstrated that the ABA signaling pathway was constitutively activated in the Arabidopsis CESA4, CESA7,
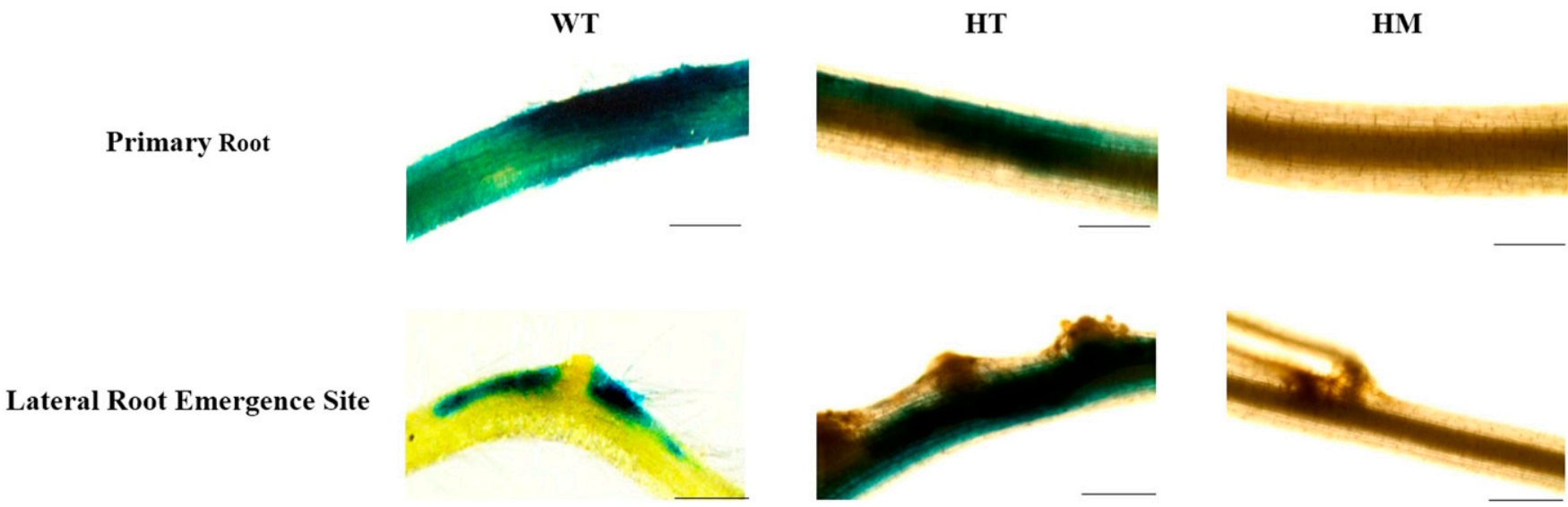

Fig. 4. Patterns of Gluconacetobacter diazotrophicus colonization in BdCESA8 T-DNA mutants. The first row is the comparison of G. diazotrophicus colonization in primary roots in different genotype groups. The second row is a comparison of G. diazotrophicus colonization at lateral root emergence sites in different genotype groups. Scale bar $=1 \mathrm{~mm}$. WT = wild type, $\mathrm{HT}=$ heterozygous mutant, and HM = homozygous mutant. 
and CESA 8 mutants and the mutants exhibited enhanced resistance to $P$. cucumerina (Hernández-Blanco et al. 2007). In agreement with these data, research showed that over half of the constitutively upregulated genes in the CESA4, CESA7, and CESA8 mutants are $\mathrm{ABA}$ responsive. Among these ABAresponsive genes, some such as $N E C D 3, A B I 1, A B I 2$, and $A B I 4$ are identified to be involved in ABA biosynthesis and signaling (Hernández-Blanco et al. 2007; Shinozaki et al. 2003). In double mutants that are impaired in both CESA8 and genes in the JA/
ET pathway, the resistance to $R$. solanacearum and $P$. cucumerina is not affected. This result indicates that JA/ET did not contribute to the increased resistance in CESA 8 mutant plants (Hernández-Blanco et al. 2007).

In the CESA4, CESA7, and CESA 8 mutants, some ABAregulated genes were also found to encode antimicrobial peptides such as lipid transfer proteins and thionins (Molina et al. 1993), or regulators of antimicrobial secondary metabolite biosynthesis such as ATRl (Grubb and Abel 2006). The

A
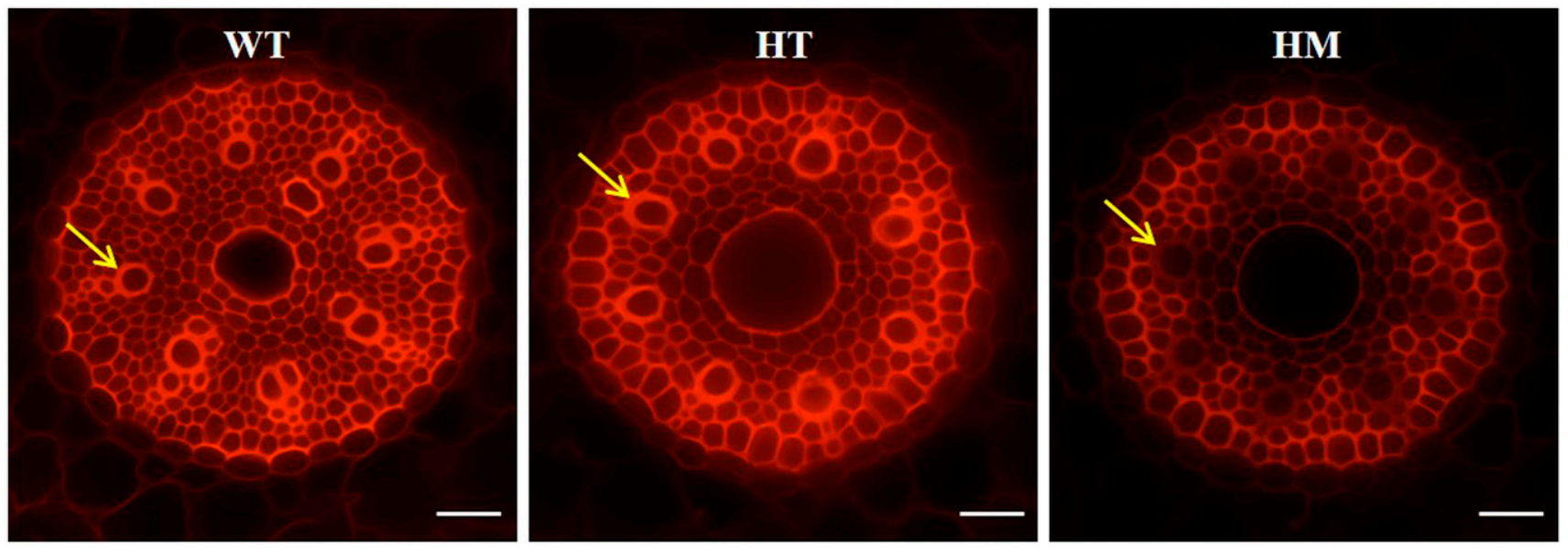

B

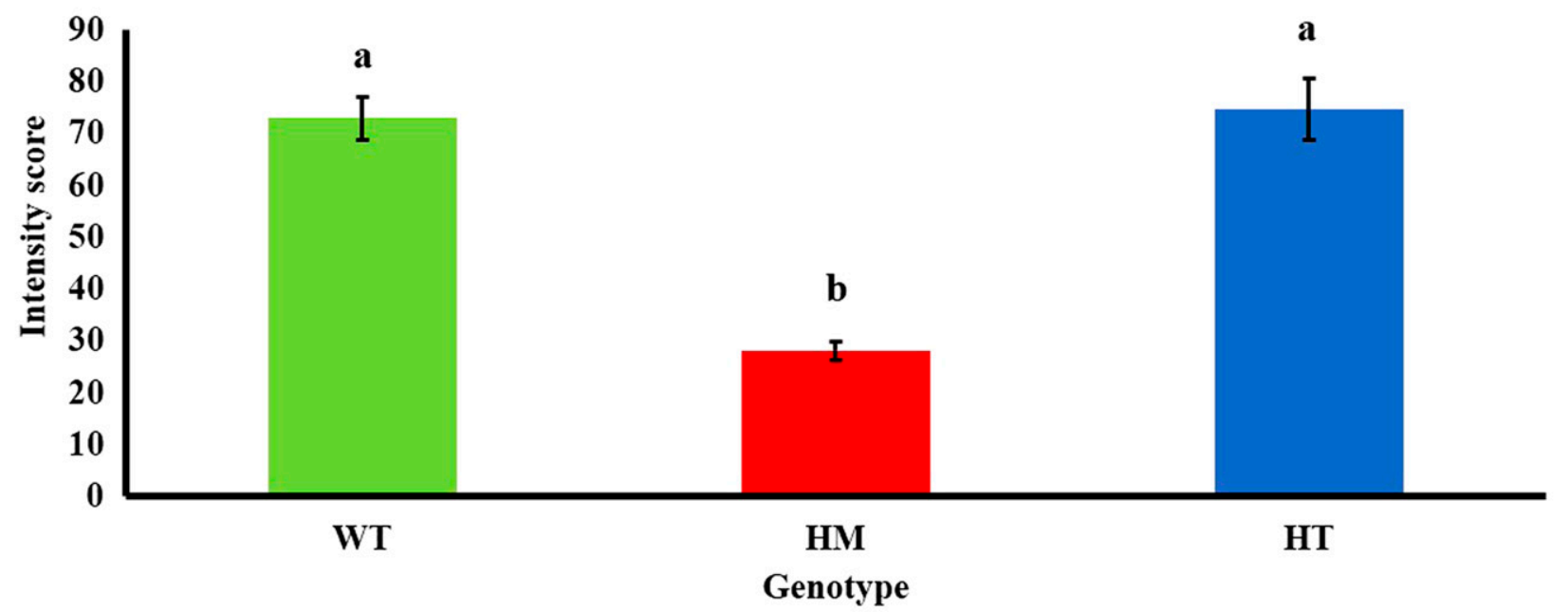

C

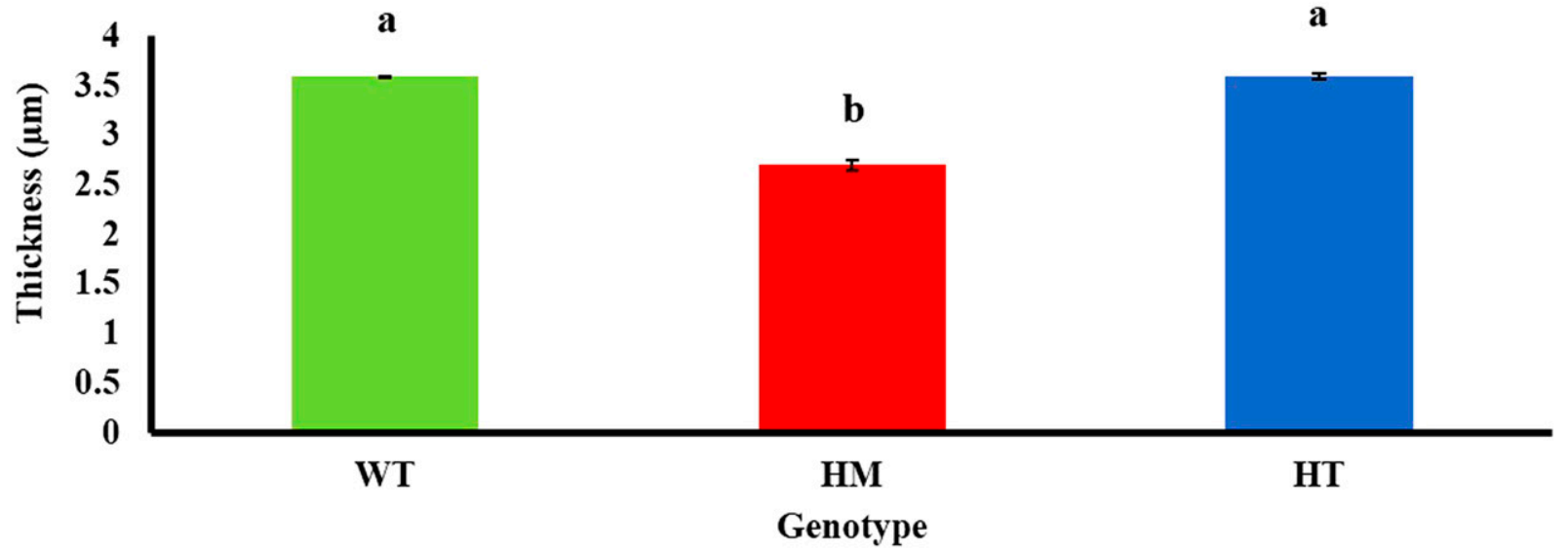

Fig. 5. Cellulose content in roots of BdCESA 8 T-DNA mutants. A, Comparison of root stele area among different genotype groups. Scale bar $=25 \mu \mathrm{m}$ $\mathbf{B}$, Cellulose content in xylem vessels among different genotype groups. C, The thickness of xylem vessels among different genotype groups. Different letters (a, b, and c) indicate significant differences among different genotypes (analysis of variance, $P<0.001$ ). Error bars represent the standard errors of four replicates for each genotype group. WT = wild type, HT = heterozygous mutant, and HM = homozygous mutant. 
accumulation of these antimicrobial peptides and secondary metabolites in these mutants can also explain, in part, their enhanced resistance to pathogens (Hernández-Blanco et al. 2007). The success of $G$. diazotrophicus colonization in BdCESA8 knockout mutant plants is significantly lower than the success in wild-type plants (Table 4). According to the differential expression profile of $G$. diazotrophicus-colonized Brachypodium roots, transcriptional expression change was induced in 60 putative ABA-responsive genes. This result suggests that ABA pathways are involved in $G$. diazotrophicus colonization and changes in the ABA pathways could potentially impact $G$. diazotrophicus colonization in Brachypodium. Based on the findings in CESA8 mutants in Arabidopsis (Grubb and Abel 2006; Hernández-Blanco et al. 2007), the constitutive activation of the ABA-meditated plant defense response by BdCESA 8 impairment and a hostile environment created by accumulation of antimicrobial compounds is a possible explanation for the results observed in this study. RNA sequencing analysis of BdCESA8 mutants to measure transcriptional expression changes in $\mathrm{ABA}$ signaling pathways or responsive networks and biochemical analysis to detect $\mathrm{ABA}$ and antimicrobial compound accumulation in BdCESA 8 knockout mutants can be used to test the hypothesis.

\section{Conclusion.}

The results of this study show that Brachypodium accommodates $G$. diazotrophicus colonization by downregulating $\mathrm{N}$ assimilation and modulating a number of phytohormone pathways such as JA, ET, and GA biosynthesis. Furthermore, the cell-wall-related processes, especially cellulose synthesis, are significantly downregulated. BdCESA8 is a key gene that functions in cellulose synthesis of xylem, and the knockout mutation in BdCESA8 can prevent $G$. diazotrophicus colonization. A better understanding of the interaction between different plant hormones and the regulation of cell wall modification during $G$. diazotrophicus colonization could greatly facilitate the progress of establishing more efficient and stable beneficial colonization and move research a step closer toward utilizing N-fixing endophytes $G$. diazotrophicus in crop production.

\section{MATERIALS AND METHODS}

\section{Bacterial culture and inoculation.}

The G. diazotrophicus strain used in this study is UAP 5541/ pRGS561 (provided by Dr. Kevin Vessey, Saint Mary's University, Halifax, Nova Scotia, Canada), which has a $\beta$-glucuronidase (GUS) reporter gene fused to the bacterial genome for the easy detection of bacterial presence via a GUS staining assay (Fuentes-Ramírez et al. 1999). The bacterium was cultured in LGIP medium (Cavalcante and Dobereiner 1988) at $28^{\circ} \mathrm{C}$ for $48 \mathrm{~h}$. The bacterial cultures were centrifuged at $8,000 \times g$ for $10 \mathrm{~min}$, resuspended in $0.8 \% \mathrm{NaCl}$ solution, then serial diluted to a final concentration of approximately $10^{8} \mathrm{CFU} / \mathrm{ml}$ (equivalent to an optical density at $600 \mathrm{~nm}$ of approximately 0.02 ) for inoculation. To inoculate the plants, the roots of 7- to 9-day-old Brachypodium seedlings were soaked in the bacterial suspension for $1 \mathrm{~h}$. The roots of control plants were soaked in $0.8 \% \mathrm{NaCl}$ solution. After the inoculation, the roots of Brachypodium seedlings were rinsed with sterile water three times, then transferred into Magenta boxes containing $120 \mathrm{ml}$ of $\mathrm{N}$-free Hoagland solution (Hoagland and Arnon 1950).

\section{Plant material and growth conditions.}

For all experiments involved in G. diazotrophicus inoculation, the $B$. distachyon seed were surface sterilized before germination. After removing the lemma, the seed were soaked in $70 \%$ ethanol for $30 \mathrm{~s}$, then washed with sterile deionized water three times. The seed were gently shaken in $1.3 \%$ sodium hypochlorite solution for $4 \mathrm{~min}$, followed by three thorough rinses with sterile deionized water, and plated on a sterile filter paper saturated with sterile water in a sterile Petri dish. Before the inoculation, the seed were vernalized in the dark at $4^{\circ} \mathrm{C}$ for 3 to 4 days, then transferred to $25^{\circ} \mathrm{C}$ under a 16 -h photoperiod for 4 to 5 days. After the inoculation, the seedlings were grown in $\mathrm{N}$-free Hoagland solution at $22^{\circ} \mathrm{C}$ under a 20 -h photoperiod for 3 weeks.

The T-DNA insertion mutant JJ18282 was obtained from the Department of Energy Joint Genome Institute (Walnut Creek, CA, U.S.A.). To propagate the T-DNA mutant and wild-type (Bd21-3 background) plants, the seed were vernalized as described above without surface sterilization, then transplanted into Pro-Mix BX growth media. The plants were grown in a growth room at $22^{\circ} \mathrm{C}$ under a 20 -h photoperiod until the seed were harvested.

\section{Histochemical GUS staining assay.}

To visualize the colonization of G. diazotrophicus in Brachypodium, seedlings were harvested for a GUS staining assay 3 weeks after inoculation. The seedlings were washed with sterile water three times, then immersed in GUS staining solution (Rodríguez-Andrade et al. 2015). The samples were vacuum infiltrated for $30 \mathrm{~min}$, then incubated at $37^{\circ} \mathrm{C}$ overnight. To clear chlorophyll, the staining solution was removed and replaced with $75 \%$ ethanol. The $75 \%$ ethanol was changed several times. The incubation time was $12 \mathrm{~h}$ between each $75 \%$ ethanol change until the samples were completely clear.

\section{Sample preparation for RNA sequencing.}

Brachypodium seed (Bd21) were germinated, then inoculated as described in previous sections. Both control and inoculated plants were grown in $\mathrm{N}$-free Hoagland solution and harvested 3 weeks after inoculation. The root samples were collected at the later stage of colonization to ensure that $G$. diazotrophicus colonization was successfully established in Brachypodium (based on previous observation prior to this study in our lab). For each plant sample, half of the root tissue was collected in a 2-ml Eppendorf microcentrifuge tube, instantly frozen in liquid nitrogen, then stored at $-80^{\circ} \mathrm{C}$ immediately until RNA isolation for RNA sequencing, while the other half of the root sample was used for GUS staining assay to ensure G. diazotrophicus colonization. Only the roots colonized by $G$. diazotrophicus as indicated by GUS assay were selected for RNA isolation. Three replicates for each treatment group were used to minimize variations and each replicate contained RNA from three plant samples. The total RNA from the root issues was isolated using the RNeasy Plant Mini Kit (Qiagen). Subsequently, all RNA samples were treated with DNase 1 (Invitrogen) to remove any potential genomic DNA contamination. To ensure that the quality of the RNA samples met the sequencing requirements, all RNA samples were assayed for purity on a Nanodrop 2000 (Thermo Scientific), and ribosomal RNA was reduced using a Ribo-Zero kit (EpiCentre) and assayed for suitable size distribution on a BioAnalyzer 2100 (Agilent). The sequencing libraries were constructed using the TruSeq RNA Library Prep Kit (Illumina) and sequenced at The Centre for Applied Genomics (Sick Kids Hospital, Toronto, Canada) using 100-bp paired-end reads on an Illumina HiSeq 2500 platform.

\section{RNA sequencing data analysis.}

Sequencing reads passing Illumina's internal quality control for each sample were mapped to the Phytozome Brachypodium v2.1 transcriptome using the Burrows-Wheeler Alignment tool (Li and Durbin 2009). The resulting sequence alignment maps 
were filtered to remove PCR duplicates, reads with low mapping quality $(\leq 20)$, and reads that failed to map to a unique gene using Samtools ( $\mathrm{Li}$ et al. 2009). The read counts for each gene were extracted with Samtools and imported into the Bioconductor package DESeq2 for calculating the fold change of gene expression using an FDR < 0.05 (Anders and Huber 2010; Love et al. 2014). The list of all differentially expressed transcripts was uploaded to Gene Ontology Consortium website for GO analysis. GO term enrichment was calculated using the Fisher's exact test with Benjamini-Hochberg correction FDR $<0.05$. The expression data for all differentially expressed genes were uploaded to the Plant Metabolic Network and overlaid onto the Brachypodium metabolic map in the BrachypodiumCyc database to visualize the expression change in metabolic pathways. Because bacterial colonization is considered as a type of biotic stress for the host plant, the MapMan software (Usadel et al. 2009) was employed to specifically visualize the pathways that changed in response to biotic stress.

\section{qPCR relative gene expression analysis.}

Colonized Brachypodium root samples were used for validating of RNA sequencing results and leaf samples were used for analyzing $B d C E S A 8$ expression in BdCESA 8 mutants. RNA was extracted using the Plant/Fungi Total RNA Purification Kit (Norgen). For each plant sample, $1 \mu \mathrm{g}$ of total RNA was reverse transcribed into cDNA using the iScript Reverse Transcription Supermix (Bio-Rad Laboratories). The thermocycler program used for reverse transcription entailed priming at $25^{\circ} \mathrm{C}$ for $5 \mathrm{~min}$, reverse transcription at $42^{\circ} \mathrm{C}$ for $30 \mathrm{~min}$, and inactivation of reverse transcription at $85^{\circ} \mathrm{C}$ for $5 \mathrm{~min}$. All qPCR assays were conducted using the SsoFast EvaGreen SuperMix (BioRad Laboratories). The thermocycling program used in the qPCR consisted of an initial phase of $95^{\circ} \mathrm{C}$ for $5 \mathrm{~min}, 40$ cycles of denaturation phase $\left(95^{\circ} \mathrm{C}\right.$ for $\left.30 \mathrm{~s}\right)$, and annealing or extension phase $\left(60^{\circ} \mathrm{C}\right.$ for $\left.45 \mathrm{~s}\right)$. This was followed by $40 \mathrm{~min}$ of melting curve analysis starting at $65^{\circ} \mathrm{C}$ and increasing to $95^{\circ} \mathrm{C}$ with $0.5^{\circ} \mathrm{C}$ increments. The Bio-Rad CFX96 real-time PCR system was used to run the qPCR program and record the fluorophore activity, and the CFX Manager Software (Bio-Rad Laboratories) was used to determine the cycle threshold values. The relative gene expression was calculated using $2^{-\Delta \Delta C t}$ method (Livak and Schmittgen 2001). Ubi4, a gene that encodes a polyubiquitin, was used as the internal reference gene (Hong et al. 2008). The primers used in all of the qPCR assays are listed in Supplementary Table S3.

\section{Phylogenetic analysis.}

The amino acid sequences of all members of the CESA gene family in A. thaliana, rice, and Brachypodium were downloaded from Phytozome. The sequences were then uploaded to the online software PhyML 3.0 and using SMS in substitution model, NNI mode in tree searching, and aLRT-SH like mode for maximum likelihood in branch support (Guindon et al. 2010; Lefort et al. 2017) for phylogenetic tree construction.

\section{Plant genomic DNA extraction.}

A second leaf of 5-week-old plants was collected in a 2-ml Eppendorf tube, frozen in liquid nitrogen, and ground into fine powder using a TissueLyser (Roche Applied Science). Extraction buffer $(500 \mu \mathrm{l})$ was added and vortexed for $15 \mathrm{~s}$ to homogenize the leaf tissue. The sample was incubated for $1 \mathrm{~h}$ at $60^{\circ} \mathrm{C}$. After the incubation, $500 \mu \mathrm{l}$ of chloroform was added and briefly vortexed. The samples were centrifuged for $5 \mathrm{~min}$ at $13,000 \times g$. The upper aqueous phase was transferred to a fresh $1.5-\mathrm{ml}$ microcentrifuge tube and $280 \mu \mathrm{l}$ of isopropanol was added. The tube was inverted several times to mix the content and centrifuged for $15 \mathrm{~min}$ at $13,000 \times g$. The supernatant was discarded without disturbing the DNA pellet precipitated at the bottom of the tube. The DNA pellet was washed twice with $500 \mu \mathrm{l}$ of $70 \%$ ethanol. The residual ethanol was removed by drying at room temperature. After the ethanol was completely evaporated, the DNA pellet was dissolved in $50 \mu \mathrm{l}$ of sterile deionized water.

\section{Genotyping of T-DNA insertion mutant.}

Three primers were used in genotyping: JJ18282 F, JJ18282 $\mathrm{R}$, and T3. The primer sequences are listed in Supplementary Table S4. Primer JJ18282 F is designed to amplify the gene sequence from approximately $400 \mathrm{bp}$ upstream of the T-DNA insertion site on gene Bradi2g49912. Primer JJ18282 R is designed to amplify the gene sequence approximately $500 \mathrm{bp}$ downstream of the T-DNA insertion site on gene Bradi2g49912. Primer T3 is used to flank the left border sequence of the T-DNA insertion. The thermocycling program used in genotyping had an initial phase of $95^{\circ} \mathrm{C}$ for $2 \mathrm{~min}$, then 32 cycles of denaturation at $95^{\circ} \mathrm{C}$ for $30 \mathrm{~s}$, annealing at $60^{\circ} \mathrm{C}$ for $30 \mathrm{~s}$, and extension at $72^{\circ} \mathrm{C}$ for $1 \mathrm{~min}$. This was followed by a final extension at $72^{\circ} \mathrm{C}$ for $5 \mathrm{~min}$.

\section{Embedding, sectioning, and staining of root samples.}

The first $2 \mathrm{~cm}$ of 28-day-old primary roots of T-DNA mutant plants was sectioned and stained for microscopic analysis. The fresh root samples were cut into $1-\mathrm{cm}$ sections just before embedding. A 5\% (wt/vol) agarose solution was used as embedding material. The agarose was dissolved in distilled water by microwaving it for $25 \mathrm{~min}$ at $10 \%$ intensity in a $1,200-\mathrm{W}$ microwave. The melted agarose was cooled at room temperature until it reached $50^{\circ} \mathrm{C}$. The agarose solution was gently poured into a clean Petri dish containing root samples to avoid air bubble formation. The agarose was left at room temperature to solidify, then stored at $4^{\circ} \mathrm{C}$ until sectioning.

The agarose-embedded root samples were cut into blocks of approximately $1.2 \mathrm{~cm}$ in length and $0.5 \mathrm{~cm}$ in width. The samples were mounted on a clean and completely dry specimen disc of a vibratome (Leica VT1000 S), placed in parallel with the sectioning razor blade, then completely submerged in distilled water in the buffer tray. The cutting speed was set at $0.225 \mathrm{~mm} / \mathrm{s}$ and the frequency was set at $50 \mathrm{~Hz}$. The thickness of the sections was $30 \mu \mathrm{m}$.

To stain the cellulose content in the root samples, a fluorescent dye called Pontamine Fast Scarlet 4B or Direct Red 23 (Sigma-Aldrich) was employed (Anderson et al. 2010). The root sections were stained in $0.1 \%$ (wt/vol) Direct Red 23 solution for $30 \mathrm{~min}$, rinsed with distilled water three times, then transferred onto glass slides for microscopic analysis.

\section{Microscopic analysis.}

The stained root cross-section samples were observed under an Eclipse Ni-E microscope (Nikon) and imaged using a DS-Ri2 camera (Nikon). The fluorescence excitation range of Direct Red 23 was set at 530 to $560 \mathrm{~nm}$. The images, which were captured at $\times 400$ magnification, were used for xylem vessel thickness and cellulose content measurements. The xylem vessel thickness was measured by NIS-Elements Analysis software (Nikon). The cellulose content was quantified using fluorescence intensity, as measured by freehand tracing around a region's perimeter in Image 2 software.

Four primary root samples were analyzed for each genotype group and three sections were used to analyze each root sample. For each section, four xylem vessels were measured for their cellulose content and the thickness of the vessels. The cellulose content of the secondary cell wall was measured using the fluorescence intensity of the xylem vessel area, and the thickness of a xylem vessel is represented by the average thickness of the three thickest points on the vessel (Supplementary Fig. S6). 


\section{Statistical analysis.}

The data analysis for experiments was conducted using an analysis of variance with a post-hoc Tukey's test to assess for significant differences between multiple groups and two-tailed Z test for percent colonization comparison. The significance level used for all statistical analyses was $\alpha=0.05$ and all statistical analyses were performed using IBM SPSS Statistics for Windows software (version 21.0; IBM Corp., Armonk, NY, U.S.A.).

\section{Data availability.}

The filtered clean RNA sequencing reads were deposited in the short read archive at NIH under Project ID PRJNA586882.

\section{ACKNOWLEDGMENTS}

We thank K. Vessey for providing bacterial strains and K. Szczyglowski for providing equipment and technical advice on microscopic analysis of root sections.

\section{AUTHOR-RECOMMENDED INTERNET RESOURCES}

Gene Ontology Consortium website: http://geneontology.org

ImageJ2 software: https://imagej.net/software/imagej2

Phytozome: http://phytozome.jgi.doe.gov

Plant Metabolic Network: https://www.plantcyc.org

\section{LITERATURE CITED}

Anders, S., and Huber, W. 2010. Differential expression analysis for sequence count data. Genome Biol. 11:R106.

Anderson, C. T., Carroll, A., Akhmetova, L., and Somerville, C. 2010. Real-time imaging of cellulose reorientation during cell wall expansion in Arabidopsis roots. Plant Physiol. 152:787-796.

Bacete, L., Mélida, H., Miedes, E., and Molina, A. 2018. Plant cell wallmediated immunity: Cell wall changes trigger disease resistance responses. Plant J. 93:614-636.

Bari, R., and Jones, J. D. G. 2009. Role of plant hormones in plant defence responses. Plant Mol. Biol. 69:473-488.

Besset-Manzoni, Y., Rieusset, L., Joly, P., Comte, G., and Prigent-Combaret, C. 2018. Exploiting rhizosphere microbial cooperation for developing sustainable agriculture strategies. Environ. Sci. Pollut. Res. Int. 25:29953-29970.

Bhargava, A., Clabaugh, I., To, J. P., Maxwell, B. B., Chiang, Y.-H., Schaller, G. E., Loraine, A., and Kieber, J. J. 2013. Identification of cytokinin-responsive genes using microarray meta-analysis and RNASeq in Arabidopsis. Plant Physiol. 162:272-294.

Bhuiyan, N. H., Selvaraj, G., Wei, Y., and King, J. 2009. Gene expression profiling and silencing reveal that monolignol biosynthesis plays a critical role in penetration defence in wheat against powdery mildew invasion. J. Exp. Bot. 60:509-521.

Boddey, R. M., Polidoro, J. C., Resende, A. S., Alves, B. J. R., and Urquiaga, S. 2001. Use of the ${ }^{15} \mathrm{~N}$ natural abundance technique for the quantification of the contribution of $\mathrm{N}_{2}$ fixation to sugar cane and other grasses. Funct. Plant Biol. 28:889-895.

Bordiec, S., Paquis, S., Lacroix, H., Dhondt, S., Ait Barka, E., Kauffmann, S., Jeandet, P., Mazeyrat-Gourbeyre, F., Clément, C., Baillieul, F., and Dorey, S. 2011. Comparative analysis of defence responses induced by the endophytic plant growth-promoting rhizobacterium Burkholderia phytofirmans strain PsJN and the non-host bacterium Pseudomonas syringae pv. pisi in grapevine cell suspensions. J. Exp. Bot. 62:595-603.

Bragg, J. N., Wu, J., Gordon, S. P., Guttman, M. E., Thilmony, R., Lazo, G. R., Gu, Y. Q., and Vogel, J. P. 2012. Generation and characterization of the Western Regional Research Center Brachypodium T-DNA insertional mutant collection. PLoS One 7:e41916.

Brkljacic, J., Grotewold, E., Scholl, R., Mockler, T., Garvin, D. F., Vain, P., Brutnell, T., Sibout, R., Bevan, M., Budak, H., Caicedo, A. L., Gao, C., Gu, Y., Hazen, S. P., Holt, B. F., 3rd, Hong, S. Y., Jordan, M., Manzaneda, A. J., Mitchell-Olds, T., Mochida, K., Mur, L. A. J., Park, C. M., Sedbrook, J., Watt, M., Zheng, S. J., and Vogel, J. P. 2011. Brachypodium as a model for the grasses: Today and the future. Plant Physiol. 157:3-13.
Brunelle, T., Dumas, P., Souty, F., Dorin, B., and Nadaud, F. 2015. Evaluating the impact of rising fertilizer prices on crop yields. Agric. Econ. 46:653-666.

Brutnell, T. P., Bennetzen, J. L., and Vogel, J. P. 2015. Brachypodium distachyon and Setaria viridis: Model genetic systems for the grasses. Annu. Rev. Plant Biol. 66:465-485.

Brutus, A., Sicilia, F., Macone, A., Cervone, F., and De Lorenzo, G. 2010. A domain swap approach reveals a role of the plant wallassociated kinase 1 (WAK1) as a receptor of oligogalacturonides. Proc. Natl. Acad. Sci. U.S.A. 107:9452-9457.

Cao, J., Jiang, M., Li, P., and Chu, Z. 2016. Genome-wide identification and evolutionary analyses of the PP2C gene family with their expression profiling in response to multiple stresses in Brachypodium distachyon. BMC Genomics 17:175.

Cardoso, T. F., Cánovas, A., Canela-Xandri, O., González-Prendes, R., Amills, M., and Quintanilla, R. 2017. RNA-seq based detection of differentially expressed genes in the skeletal muscle of Duroc pigs with distinct lipid profiles. Sci. Rep. 7:40005.

Cass, C. L., Peraldi, A., Dowd, P. F., Mottiar, Y., Santoro, N., Karlen, S. D., Bukhman, Y. V., Foster, C. E., Thrower, N., Bruno, L. C., Moskvin, O. V., Johnson, E. T., Willhoit, M. E., Phutane, M., Ralph, J., Mansfield, S. D., Nicholson, P., and Sedbrook, J. C. 2015. Effects of PHENYLALANINE AMMONIA LYASE (PAL) knockdown on cell wall composition, biomass digestibility, and biotic and abiotic stress responses in Brachypodium. J. Exp. Bot. 66:4317-4335.

Cassman, K. G., Dobermann, A., Walters, D. T., and Yang, H. 2003. Meeting cereal demand while protecting natural resources and improving environmental quality. Annu. Rev. Environ. Resour. 28:315-358.

Cavalcante, V. A., and Dobereiner, J. 1988. A new acid-tolerant nitrogen-fixing bacterium associated with sugarcane. Plant Soil 108:23-31.

Chen, Z., Hong, X., Zhang, H., Wang, Y., Li, X., Zhu, J. K., and Gong, Z. 2005. Disruption of the cellulose synthase gene, AtCesA8/IRXI, enhances drought and osmotic stress tolerance in Arabidopsis. Plant J. 43:273-283.

Conn, V. M., Walker, A. R., and Franco, C. M. 2008. Endophytic actinobacteria induce defense pathways in Arabidopsis thaliana. Mol. PlantMicrobe Interact. 21:208-218.

Crawford, N. M., and Forde, B. G. 2002. Molecular and developmental biology of inorganic nitrogen nutrition. Arabidopsis Book 1:e0011.

Delledonne, M., Zeier, J., Marocco, A., and Lamb, C. 2001. Signal interactions between nitric oxide and reactive oxygen intermediates in the plant hypersensitive disease resistance response. Proc. Natl. Acad. Sci. U.S.A. 98:13454-13459.

Denness, L., McKenna, J. F., Segonzac, C., Wormit, A., Madhou, P., Bennett, M., Mansfield, J., Zipfel, C., and Hamann, T. 2011. Cell wall damage-induced lignin biosynthesis is regulated by a reactive oxygen species- and jasmonic acid-dependent process in Arabidopsis. Plant Physiol. 156:1364-1374.

Dent, D., and Cocking, E. 2017. Establishing symbiotic nitrogen fixation in cereals and other non-legume crops: The greener nitrogen revolution. Agric. Food Secur. 6:7.

Desprez, T., Juraniec, M., Crowell, E. F., Jouy, H., Pochylova, Z., Parcy, F., Höfte, H., Gonneau, M., and Vernhettes, S. 2007. Organization of cellulose synthase complexes involved in primary cell wall synthesis in Arabidopsis thaliana. Proc. Natl. Acad. Sci. U.S.A. 104:1557215577.

Endler, A., and Persson, S. 2011. Cellulose synthases and synthesis in Arabidopsis. Mol. Plant 4:199-211.

Engelsdorf, T., and Hamann, T. 2014. An update on receptor-like kinase involvement in the maintenance of plant cell wall integrity. Ann. Bot. 114:1339-1347.

Erisman, J. W., Sutton, M. A., Galloway, J., Klimont, Z., and Winiwarter, W. 2008. How a century of ammonia synthesis changed the world. Nat. Geosci. 1:636-639.

Farrar, K., Bryant, D., and Cope-Selby, N. 2014. Understanding and engineering beneficial plant-microbe interactions: Plant growth promotion in energy crops. Plant Biotechnol. J. 12:1193-1206.

Febrer, M., Goicoechea, J. L., Wright, J., McKenzie, N., Song, X., Lin, J., Collura, K., Wissotski, M., Yu, Y., Ammiraju, J. S. S., Wolny, E., Idziak, D., Betekhtin, A., Kudrna, D., Hasterok, R., Wing, R. A., and Bevan, M. W. 2010. An integrated physical, genetic and cytogenetic map of Brachypodium distachyon, a model system for grass research. PLoS One 5:e13461.

Fei, H., Crouse, M., Papadopoulos, Y. A., and Vessey, J. K. 2020. Improving biomass yield of giant Miscanthus by application of beneficial soil microbes and a plant biostimulant. Can. J. Plant Sci. 100:2939. 
Fischer, R. A., Byerlee, D., and Edmeades, G. O. 2009. Can technology deliver on the yield challenge to 2050. FAO Expert Meeting on How to Feed the World in 2050. 24-26 June, Rome, Italy.

Fowler, D., Coyle, M., Skiba, U., Sutton, M. A., Cape, J. N., Reis, S., Sheppard, L. J., Jenkins, A., Grizzetti, B., Galloway, J. N., Vitousek, P., Leach, A., Bouwman, A. F., Butterbach-Bahl, K., Dentener, F., Stevenson, D., Amann, M., and Voss, M. 2013. The global nitrogen cycle in the twenty-first century. Philos. Trans. R. Soc. Lond. B Biol. Sci. 368:20130164.

Fuentes-Ramírez, L. E., Caballero-Mellado, J., Sepúlveda, J., and Martínez-Romero, E. 1999. Colonization of sugarcane by Acetobacter diazotrophicus is inhibited by high $\mathrm{N}$-fertilization. FEMS Microbiol. Ecol. 29:117-128.

Gherbi, H., Markmann, K., Svistoonoff, S., Estevan, J., Autran, D., Giczey, G., Auguy, F., Péret, B., Laplaze, L., Franche, C., Parniske, M., and Bogusz, D. 2008. SymRK defines a common genetic basis for plant root endosymbioses with arbuscular mycorrhiza fungi, rhizobia, and Frankiabacteria. Proc. Natl. Acad. Sci. U.S.A. 105:4928-4932.

Grubb, C. D., and Abel, S. 2006. Glucosinolate metabolism and its control. Trends Plant Sci. 11:89-100.

Guindon, S., Dufayard, J. F., Lefort, V., Anisimova, M., Hordijk, W., and Gascuel, O. 2010. New algorithms and methods to estimate maximum-likelihood phylogenies: Assessing the performance of PhyML 3.0. Syst. Biol. 59:307-321.

Gust, A. A., Willmann, R., Desaki, Y., Grabherr, H. M., and Nürnberger, T. 2012. Plant LysM proteins: Modules mediating symbiosis and immunity. Trends Plant Sci. 17:495-502.

Hamann, T. 2012. Plant cell wall integrity maintenance as an essential component of biotic stress response mechanisms. Front. Plant Sci. 3: 77.

Hématy, K., Cherk, C., and Somerville, S. 2009. Host-pathogen warfare at the plant cell wall. Curr. Opin. Plant Biol. 12:406-413.

Hernández-Blanco, C., Feng, D. X., Hu, J., Sánchez-Vallet, A., Deslandes, L., Llorente, F., Berrocal-Lobo, M., Keller, H., Barlet, X., Sánchez-Rodríguez, C., Anderson, L. K., Somerville, S., Marco, Y., and Molina, A. 2007. Impairment of cellulose synthases required for Arabidopsis secondary cell wall formation enhances disease resistance. Plant Cell 19:890-903.

Hirel, B., Tétu, T., Lea, P. J., and Dubois, F. 2011. Improving nitrogen use efficiency in crops for sustainable agriculture. Sustainability 3: 1452-1485.

Hoagland, D. R., and Arnon, D. I. 1950. Water-Culture Method for Growing Plants Without Soil. University of California, College of Agriculture, Berkley, CA, U.S.A.

Hong, S.-Y., Seo, P. J., Yang, M. S., Xiang, F., and Park, C. M. 2008 Exploring valid reference genes for gene expression studies in Brachypodium distachyon by real-time PCR. BMC Plant Biol. 8:112.

Hsia, M. M., O’Malley, R., Cartwright, A., Nieu, R., Gordon, S. P., Kelly, S., Williams, T. G., Wood, D. F., Zhao, Y., Bragg, J., Jordan, M., Pauly, M., Ecker, J. R., Gu, Y., and Vogel, J. P. 2017. Sequencing and functional validation of the JGI Brachypodium distachyon T-DNA collection. Plant J. 91:361-370.

Iniguez, A. L., Dong, Y., Carter, H. D., Ahmer, B. M., Stone, J. M., and Triplett, E. W. 2005. Regulation of enteric endophytic bacterial colonization by plant defenses. Mol. Plant-Microbe Interact. 18:169-178.

Jimenez-Salgado, T., Fuentes-Ramirez, L. E., Tapia-Hernandez, A., Mascarua-Esparza, M. A., Martinez-Romero, E., and Caballero-Mellado, J. 1997. Coffea arabica L., a new host plant for Acetobacter diazotrophicus, and isolation of other nitrogen-fixing acetobacteria. Appl. Environ. Microbiol. 63:3676-3683.

Kakei, Y., Mochida, K., Sakurai, T., Yoshida, T., Shinozaki, K., and Shimada, Y. 2015. Transcriptome analysis of hormone-induced gene expression in Brachypodium distachyon. Sci. Rep. 5:14476.

Kant, S., Bi, Y.-M., and Rothstein, S. J. 2011. Understanding plant response to nitrogen limitation for the improvement of crop nitrogen use efficiency. J. Exp. Bot. 62:1499-1509.

Ke, X., Feng, S., Wang, J., Lu, W., Zhang, W., Chen, M., and Lin, M. 2019. Effect of inoculation with nitrogen-fixing bacterium Pseudomonas stutzeri A1501 on maize plant growth and the microbiome indigenous to the rhizosphere. Syst. Appl. Microbiol. 42:248-260.

Kohorn, B. D., Johansen, S., Shishido, A., Todorova, T., Martinez, R., Defeo, E., and Obregon, P. 2009. Pectin activation of MAP kinase and gene expression is WAK2 dependent. Plant J. 60:974-982.

Kudoyarova, G., Arkhipova, T., Korshunova, T., Bakaeva, M., Loginov, O., and Dodd, I. C. 2019. Phytohormone meditation of interactions between plants and non-symbiotic growth promoting bacteria under edaphic stresses. Front. Plant Sci. 10:1368.
Kumar, M., Campbell, L., and Turner, S. 2016. Secondary cell walls: Biosynthesis and manipulation. J. Exp. Bot. 67:515-531.

Ladha, J. K., Tirol-Padre, A., Reddy, C. K., Cassman, K. G., Verma, S., Powlson, D. S., van Kessel, C., de B Richter, D., Chakraborty, D., and Pathak, H. 2016. Global nitrogen budgets in cereals: A 50-year assessment for maize, rice, and wheat production systems. Sci. Rep. 6: 19355.

Lassaletta, L., Billen, G., Grizzetti, B., Anglade, J., and Garnier, J. 2014. 50 Year trends in nitrogen use efficiency of world cropping systems: The relationship between yield and nitrogen input to cropland. Environ. Res. Lett. 9:105011.

Lee, S., Rojas, C. M., Oh, S., Kang, M., Choudhury, S. R., Lee, H. K., Allen, R. D., Pandey, S., and Mysore, K. S. 2018. Nucleolar GTPbinding protein 1-2 (NOG1-2) interacts with jasmonate-ZIM-domain protein 9 (JAZ9) to regulate stomatal aperture during plant immunity. Int. J. Mol. Sci. 19:1922.

Lefort, V., Longueville, J. E., and Gascuel, O. 2017. SMS: Smart model selection in PhyML. Mol. Biol. Evol. 34:2422-2424.

Li, H., and Durbin, R. 2009. Fast and accurate short read alignment with Burrows-Wheeler transform. Bioinformatics 25:1754-1760.

Li, H., Handsaker, B., Wysoker, A., Fennell, T., Ruan, J., Homer, N., Marth, G., Abecasis, G., Durbin, R., and 1000 Genome Project Data Processing Subgroup. 2009. The sequence alignment/map format and Samtools. Bioinformatics 25:2078-2079.

Liu, H., Carvalhais, L. C., Crawford, M., Singh, E., Dennis, P. G., Pieterse, C. M. J., and Schenk, P. M. 2017. Inner plant values: Diversity, colonization and benefits from endophytic bacteria. Front. Microbiol. $8: 2552$.

Livak, K. J., and Schmittgen, T. D. 2001. Analysis of relative gene expression data using real-time quantitative PCR and the $2^{-\Delta \Delta C T}$ method. Methods 25:402-408.

Loqué, D., Scheller, H. V., and Pauly, M. 2015. Engineering of plant cell walls for enhanced biofuel production. Curr. Opin. Plant Biol. 25:151161.

Love, M. I., Huber, W., and Anders, S. 2014. Moderated estimation of fold change and dispersion for RNA-seq data with DESeq2. Genome Biol. 15:550.

Luna, M. F., Galar, M. L., Aprea, J., Molinari, M. L., and Boiardi, J. L. 2010. Colonization of sorghum and wheat by seed inoculation with Gluconacetobacter diazotrophicus. Biotechnol. Lett. 32:1071-1076.

Macho, A. P., and Zipfel, C. 2014. Plant PRRs and the activation of innate immune signaling. Mol. Cell 54:263-272.

MacLean, A. M., Bravo, A., and Harrison, M. J. 2017. Plant signaling and metabolic pathways enabling arbuscular mycorrhizal symbiosis. Plant Cell 29:2319-2335.

Malinovsky, F. G., Fangel, J. U., and Willats, W. G. T. 2014. The role of the cell wall in plant immunity. Front. Plant Sci. 5:178.

Mendu, V., Griffiths, J. S., Persson, S., Stork, J., Downie, A. B., Voiniciuc, C., Haughn, G. W., and DeBolt, S. 2011. Subfunctionalization of cellulose synthases in seed coat epidermal cells mediates secondary radial wall synthesis and mucilage attachment. Plant Physiol. 157:441453.

Miché, L., Battistoni, F., Gemmer, S., Belghazi, M., and Reinhold-Hurek, B. 2006. Upregulation of jasmonate-inducible defense proteins and differential colonization of roots of Oryza sativa cultivars with the endophyte Azoarcus sp. Mol. Plant-Microbe Interact. 19:502-511.

Miedes, E., Vanholme, R., Boerjan, W., and Molina, A. 2014. The role of the secondary cell wall in plant resistance to pathogens. Front. Plant Sci. 5:358.

Molina, A., Segura, A., and García-Olmedo, F. 1993. Lipid transfer proteins (nsLTPs) from barley and maize leaves are potent inhibitors of bacterial and fungal plant pathogens. FEBS Lett. 316:119-122.

Mur, L. A. J., Prats, E., Pierre, S., Hall, M. A., and Hebelstrup, K. H. 2013. Integrating nitric oxide into salicylic acid and jasmonic acid/ ethylene plant defense pathways. Front. Plant Sci. 4:215.

Nafisi, M., Fimognari, L., and Sakuragi, Y. 2015. Interplays between the cell wall and phytohormones in interaction between plants and necrotrophic pathogens. Phytochemistry 112:63-71.

Nakagawa, T., Kaku, H., Shimoda, Y., Sugiyama, A., Shimamura, M., Takanashi, K., Yazaki, K., Aoki, T., Shibuya, N., and Kouchi, H. 2011. From defense to symbiosis: Limited alterations in the kinase domain of LysM receptor-like kinases are crucial for evolution of legume-Rhizobium symbiosis. Plant J. 65:169-180.

Paula, M. A., Reis, V. M., and Döbereiner, J. 1991. Interactions of Glomus clarum with Acetobacter diazotrophicus in infection of sweet potato (Ipomoea batatas), sugarcane (Saccharum spp.), and sweet sorghum (Sorghum vulgare). Biol. Fertil. Soils 11:111-115. 
Pauly, M., and Keegstra, K. 2008. Cell-wall carbohydrates and their modification as a resource for biofuels. Plant J. 54:559-568.

Persson, S., Paredez, A., Carroll, A., Palsdottir, H., Doblin, M., Poindexter, P., Khitrov, N., Auer, M., and Somerville, C. R. 2007. Genetic evidence for three unique components in primary cell-wall cellulose synthase complexes in Arabidopsis. Proc. Natl. Acad. Sci. U.S.A. 104:15566-15571.

Petrik, D. L., Cass, C. L., Padmakshan, D., Foster, C. E., Vogel, J. P., Karlen, S. D., Ralph, J., and Sedbrook, J. C. 2016. BdCESA7, BdCESA8, and BdPMT utility promoter constructs for targeted expression to secondary cell-wall-forming cells of grasses. Front. Plant Sci. 7:55.

Petrik, D. L., Karlen, S. D., Cass, C. L., Padmakshan, D., Lu, F., Liu, S., Le Bris, P., Antelme, S., Santoro, N., Wilkerson, C. G., Sibout, R., Lapierre, C., Ralph, J., and Sedbrook, J. C. 2014. p-Coumaroyl-CoA:monolignol transferase (PMT) acts specifically in the lignin biosynthetic pathway in Brachypodium distachyon. Plant J. 77:713-726.

Pogorelko, G., Lionetti, V., Bellincampi, D., and Zabotina, O. 2013. Cell wall integrity: Targeted post-synthetic modifications to reveal its role in plant growth and defense against pathogens. Plant Signal. Behav. 8: e25435.

Powell, J. J., Carere, J., Sablok, G., Fitzgerald, T. L., Stiller, J., Colgrave, M. L., Gardiner, D. M., Manners, J. M., Vogel, J. P., Henry, R. J., and Kazan, K. 2017. Transcriptome analysis of Brachypodium during fungal pathogen infection reveals both shared and distinct defense responses with wheat. Sci. Rep. 7:17212.

Radutoiu, S., Madsen, L. H., Madsen, E. B., Felle, H. H., Umehara, Y., Grønlund, M., Sato, S., Nakamura, Y., Tabata, S., Sandal, N., and Stougaard, J. 2003. Plant recognition of symbiotic bacteria requires two LysM receptor-like kinases. Nature 425:585-592.

Ramírez, V., Agorio, A., Coego, A., García-Andrade, J., Hernández, M. J., Balaguer, B., Ouwerkerk, P. B. F., Zarra, I., and Vera, P. 2011. MYB46 modulates disease susceptibility to Botrytis cinerea in Arabidopsis. Plant Physiol. 155:1920-1935.

Reinhold-Hurek, B., and Hurek, T. 2011. Living inside plants: Bacterial endophytes. Curr. Opin. Plant Biol. 14:435-443.

Rodriguez, M. V., Tano, J., Ansaldi, N., Carrau, A., Srebot, M. S., Ferreira, V., Martínez, M. L., Cortadi, A. A., Siri, M. I., and Orellano, E. G. 2019. Anatomical and biochemical changes induced by Gluconacetobacter diazotrophicus stand up for Arabidopsis thaliana seedlings from Ralstonia solanacearum infection. Front. Plant Sci. 10: 1618.

Rodríguez-Andrade, O., Fuentes-Ramírez, L. E., Morales-García, Y. E., Molina-Romero, D., Bustillos-Cristales, M. R., Martínez-Contreras, R. D., and Muñoz-Rojas, J. 2015. The decrease in the population of Gluconacetobacter diazotrophicus in sugarcane after nitrogen fertilization is related to plant physiology in split root experiments. Rev. Argent. Microbiol. 47:335-343.

Rosenblueth, M., and Martínez-Romero, E. 2006. Bacterial endophytes and their interactions with hosts. Mol. Plant-Microbe Interact. 19:827837.

Sarkar, P., Bosneaga, E., and Auer, M. 2009. Plant cell walls throughout evolution: Towards a molecular understanding of their design principles. J. Exp. Bot. 60:3615-3635.

Scholthof, K. B. G., Irigoyen, S., Catalan, P., and Mandadi, K. K. 2018. Brachypodium: A monocot grass model genus for plant biology. Plant Cell 30:1673-1694.

Seo, P. J., and Park, C. M. 2010. MYB96-mediated abscisic acid signals induce pathogen resistance response by promoting salicylic acid biosynthesis in Arabidopsis. New Phytol. 186:471-483.

Sevilla, M., Burris, R. H., Gunapala, N., and Kennedy, C. 2001. Comparison of benefit to sugarcane plant growth and ${ }^{15} \mathrm{~N}_{2}$ incorporation following inoculation of sterile plants with Acetobacter diazotrophicus wild-type and Nif mutants strains. Mol. Plant-Microbe Interact. 14: 358-366.

Sevilla, M., and Kennedy, C. 2000. Colonization of rice and other cereals by Acetobacter diazotrophicus, an endophyte of sugarcane. Pages 151165 in: The Quest for Nitrogen Fixation in Rice. J. K. Ladha and P. M. Reddy, eds. International Rice Research Institute, Los Banos, Philippines.

Sharma, L. K., and Bali, S. K. 2018. A review of methods to improve nitrogen use efficiency in agriculture. Sustainability 10:51.

Shinozaki, K., Yamaguchi-Shinozaki, K., and Seki, M. 2003. Regulatory network of gene expression in the drought and cold stress responses. Curr. Opin. Plant Biol. 6:410-417.

Silva, R., Filgueiras, L., Santos, B., Coelho, M., Silva, M., EstradaBonilla, G., Vidal, M., Baldani, J. I., and Meneses, C. 2020. Gluconacetobacter diazotrophicus changes the molecular mechanisms of root development in Oryza sativa L. growing under water stress. Int. J. Mol. Sci. 21:333.

Souza, C. A., Li, S., Lin, A. Z., Boutrot, F., Grossmann, G., Zipfel, C., and Somerville, S. C. 2017. Cellulose-derived oligomers act as damage-associated molecular patterns and trigger defense-like responses. Plant Physiol. 173:2383-2398.

Stork, J., Harris, D., Griffiths, J., Williams, B., Beisson, F., Li-Beisson, Y., Mendu, V., Haughn, G., and Debolt, S. 2010. CELLULOSE SYNTHASE9 serves a nonredundant role in secondary cell wall synthesis in Arabidopsis epidermal testa cells. Plant Physiol. 153: 580-589.

Stracke, S., Kistner, C., Yoshida, S., Mulder, L., Sato, S., Kaneko, T., Tabata, S., Sandal, N., Stougaard, J., Szczyglowski, K., and Parniske, M. 2002. A plant receptor-like kinase required for both bacterial and fungal symbiosis. Nature 417:959-962.

Subramanyam, S., Nemacheck, J. A., Hargarten, A. M., Sardesai, N., Schemerhorn, B. J., and Williams, C. E. 2019. Multiple molecular defense strategies in Brachypodium distachyon surmount Hessian fly (Mayetiola destructor) larvae-induced susceptibility for plant survival. Sci. Rep. 9:2596.

Sullivan, S., Ralet, M.-C., Berger, A., Diatloff, E., Bischoff, V., Gonneau, M., Marion-Poll, A., and North, H. M. 2011. CESA5 is required for the synthesis of cellulose with a role in structuring the adherent mucilage of Arabidopsis seeds. Plant Physiol. 156:1725-1739.

Tanaka, K., Murata, K., Yamazaki, M., Onosato, K., Miyao, A., and Hirochika, H. 2003. Three distinct rice cellulose synthase catalytic subunit genes required for cellulose synthesis in the secondary wall. Plant Physiol. 133:73-83.

Tapia-Hernández, A., Bustillos-Cristales, M. R., Jiménez-Salgado, T., Caballero-Mellado, J., and Fuentes-Ramírez, L. E. L. E. 2000. Natural endophytic occurrence of acetobacter diazotrophicus in pineapple plants. Microb. Ecol. 39:49-55.

Taylor, N. G., Howells, R. M., Huttly, A. K., Vickers, K., and Turner, S. R. 2003. Interactions among three distinct CesA proteins essential for cellulose synthesis. Proc. Natl. Acad. Sci. U.S.A. 100: 1450-1455.

Taylor, N. G., Laurie, S., and Turner, S. R. 2000. Multiple cellulose synthase catalytic subunits are required for cellulose synthesis in Arabidopsis. Plant Cell 12:2529-2539.

The International Brachypodium Initiative. 2010. Genome sequencing and analysis of the model grass Brachypodium distachyon. Nature 463:763-768.

Thole, V., Peraldi, A., Worland, B., Nicholson, P., Doonan, J. H., and Vain, P. 2012. T-DNA mutagenesis in Brachypodium distachyon. J. Exp. Bot. 63:567-576.

Tian, G., Pauls, P., Dong, Z., Reid, L. M., and Tian, L. 2009. Colonization of the nitrogen-fixing bacterium Gluconacetobacter diazotrophicus in a large number of Canadian corn plants. Can. J. Plant Sci. 89: 1009-1016.

Underwood, W. 2012. The plant cell wall: A dynamic barrier against pathogen invasion. Front. Plant Sci. 3:85.

Usadel, B., Poree, F., Nagel, A., Lohse, M., Czedik-Eysenberg, A., and Stitt, M. 2009. A guide to using MapMan to visualize and compare Omics data in plants: A case study in the crop species, Maize. Plant Cell Environ. 32:1211-1229.

Vain, P. 2011. Brachypodium as a model system for grass research. J. Cereal Sci. 54:1-7.

Verhage, A., van Wees, S. C. M., and Pieterse, C. M. J. 2010. Plant immunity: It's the hormones talking, but what do they say? Plant Physiol. 154:536-540.

Vorwerk, S., Somerville, S., and Somerville, C. 2004. The role of plant cell wall polysaccharide composition in disease resistance. Trends Plant Sci. 9:203-209.

Voxeur, A., and Höfte, H. 2016. Cell wall integrity signaling in plants: "To grow or not to grow that's the question". Glycobiology 26:950960.

Yoon, V., Tian, G., Vessey, J. K., Macfie, S. M., Dangi, O. P., Kumer, A. K., and Tian, L. 2016. Colonization efficiency of different sorghum genotypes by Gluconacetobacter diazotrophicus. Plant Soil 398:243256.

Yun, B. W., Feechan, A., Yin, M., Saidi, N. B. B., Le Bihan, T., Yu, M., Moore, J. W., Kang, J. G., Kwon, E., Spoel, S. H., Pallas, J. A., and Loake, G. J. 2011. S-nitrosylation of NADPH oxidase regulates cell death in plant immunity. Nature 478:264-268.

Zamioudis, C., and Pieterse, C. M. J. 2012. Modulation of host immunity by beneficial microbes. Mol. Plant-Microbe Interact. 25:139-150.

Zeidler, D., Zähringer, U., Gerber, I., Dubery, I., Hartung, T., Bors, W., Hutzler, P., and Durner, J. 2004. Innate immunity in Arabidopsis 
thaliana: Lipopolysaccharides activate nitric oxide synthase (NOS) and induce defense genes. Proc. Natl. Acad. Sci. U.S.A. 101:1581115816.

Zhang, X., Davidson, E. A., Mauzerall, D. L., Searchinger, T. D., Dumas, P., and Shen, Y. 2015. Managing nitrogen for sustainable development. Nature 528:51-59.
Zhao, B., Erwin, A., and Xue, B. 2018. How many differentially expressed genes: A perspective from the comparison of genotypic and phenotypic distances. Genomics 110:67-73.

Zuccaro, A., and Langen, G. 2020. Breeding for resistance: Can we increase crop resistance to pathogens without compromising the ability to accommodate beneficial microbes? New Phytol. 227:279-282. 